\title{
Study of the changes in mono-, di- and trifunctional octadecyl- modified packings for reversed-phase high-performance liquid chromatography with different eluent compositions
}

Citation for published version (APA):

Hetem, M. J. J., Ven, van de, L. J. M., Haan, de, J. W., Cramers, C. A. M. G., Albert, K., \& Bayer, E. (1989). Study of the changes in mono-, di- and trifunctional octadecyl-modified packings for reversed-phase highperformance liquid chromatography with different eluent compositions. Journal of Chromatography, 479(2), 269295. https://doi.org/10.1016/S0021-9673(01)83343-4

DOI:

10.1016/S0021-9673(01)83343-4

Document status and date:

Published: 01/01/1989

Document Version:

Publisher's PDF, also known as Version of Record (includes final page, issue and volume numbers)

\section{Please check the document version of this publication:}

- A submitted manuscript is the version of the article upon submission and before peer-review. There can be important differences between the submitted version and the official published version of record. People interested in the research are advised to contact the author for the final version of the publication, or visit the $\mathrm{DOI}$ to the publisher's website.

- The final author version and the galley proof are versions of the publication after peer review.

- The final published version features the final layout of the paper including the volume, issue and page numbers.

Link to publication

\footnotetext{
General rights

- You may freely distribute the URL identifying the publication in the public portal. follow below link for the End User Agreement:

www.tue.nl/taverne

\section{Take down policy}

If you believe that this document breaches copyright please contact us at:

openaccess@tue.nl

providing details and we will investigate your claim.
}

Copyright and moral rights for the publications made accessible in the public portal are retained by the authors and/or other copyright owners and it is a condition of accessing publications that users recognise and abide by the legal requirements associated with these rights.

- Users may download and print one copy of any publication from the public portal for the purpose of private study or research.

- You may not further distribute the material or use it for any profit-making activity or commercial gain

If the publication is distributed under the terms of Article $25 \mathrm{fa}$ of the Dutch Copyright Act, indicated by the "Taverne" license above, please 
STUDY OF THE CHANGES IN MONO-, DI- AND TRIFUNCTIONAL OCTADECYL-MODIFIED PACKINGS FOR REVERSED-PHASE HIGH-PERFORMANCE LIQUID CHROMATOGRAPHY WITH DIFFERENT ELUENT COMPOSITIONS

\author{
M. HETEM*, L. VAN DE VEN, J. DE HAAN and C. CRAMERS
}

Eindhoven University of Technology, Department of Chemical Technology, Laboratory Instrumental Analysis, P.O. Box 513, 5600 MB Eindhoven (The Netherlands)

and

K. ALBER'I and E. BAYER

Institut für Organische Chemie, Universität Tübingen, Auf der Morgenstelle 18, D-7400 Tübingen (F.R.G.)

(First received February 7th, 1989; revised manuscript received June 12th, 1989)

\title{
SUMMARY
}

Two different types of silica substrates uniformly modified with reversed-phase high-performance liquid chromatographic (RP-HPLC) phases obtained with mono-, di- and trifunctional octadecylsilanes were subjected to artificial ageing under simulated routine conditions and were subsequently analysed and evaluated. Changes in the properties of the bonded phase packings were characterized and quantified with chromatographic techniques, solid-state NMR and elemental analysis. These changes were correlated with selectivity, loss of silanes, gain in silanol content and rearrangement of the silica to silane bonding. When eluents of extremely high $\mathrm{pH}$ were used, the multifunctional octadecylsilane stationary phases showed a higher resistance towards ligand stripping. The substrate shielding of difunctional octadecylsilanes showed superior characteristics due to direct surface attachments. The rigidity of the silica substrate used for modification influences the stability of the RP-HPLC phases, especially for the monofunctionally modified octadecylsilane stationary phase. With the use of multifunctional $\mathrm{C}_{18}$ silanes for modification, the influence of the characteristics of the substrate on the stability of the RP-HPLC phases was reduced compared with monofunctional $\mathrm{C}_{18}$. In contrast to monofunctionally modified phases, the polar selectivity of the multifunctionally modified phases remained more or less constant after intensive use with aggressive eluents. A chromatographic characterization method for obtaining information about the stability, capacity, selectivity and silica degradation of different RP-HPLC stationary phases is also presented.

\section{INTRODUCTION}

The stability of chemically bonded phases on porous silica substrates employed in high-performance liquid chromatography (HPLC) has been the issue of several 
recent studies ${ }^{1-5}$. The significance of these studies becomes clear on considering the still increasing popularity of liquid-solid partition reversed-phase chromatography (RP-HPLC). The wide variations in the properties of bonded phases commercially available today for RP-HPLC applications exist as a result of considerable differences in: the structure of the silica gel generally employed as the substrate for modification and the nature of the moieties at the surface such as silanediol groups and bonded and isolated silanols ${ }^{3-9}$, the chemical properties of the ligand moieties used for modification of the porous silica ${ }^{8-15}$, the number and nature of reactive groups involved in ligand surface attachment, e.g., chloro and ethoxy groups ${ }^{10,16}$, and the reaction conditions for modifications ${ }^{17}$. These are also decisive factors with regard to the relative surface coverage of the bonded phase $\mathrm{p}^{13,17,18}$ and the type of anchoring of the ligands to the substrate $1,10,16$.

It is obvious that dissimilarities in the synthesis of chemically bonded phases not only determine the selectivity, but also influence their stability towards hydrolysis. Aggressive eluents used as mobile phases in modern RP-HPLC practice cause hydrolysis of the bonded ligands at the silica surface followed by hydrolysis of the silica substrate ${ }^{1-5}$. Although this process normally proceeds slowly, after use for some time the properties of the stationary phase alter, indicated by changes in the capacity and eventually also in the selectivity of the reversed phase.

In this study, the interference of various eluents used in LC practice, with octadecylsilane RP-HPLC stationary phases modified on two different silica substrates and with various ligand anchorings, comprising six phases altogether, were examined by chromatography, elemental analysis and high-resolution solid-state ${ }^{29} \mathrm{Si}$ NMR.

The two silica substrates with different physical properties and chemical nature of the silica surface were uniformly modified with mono-, di- and trifunctional octadecylsilanes $\left(\mathrm{C}_{18}\right)$ to obtain mono-, di- and even tridentate linkages of the $\mathrm{C}_{18}$ ligands with the silica surface and neighbours (cross-linking). The reaction conditions employed for modification were such that for all six bonded $C_{18}$ phases an equal relative coverage of the octadecylsilanes at the surface was obtained. Much to our surprise, identical reaction conditions could be cmployed. The influence of the properties of the substrate, the anchoring of the ligands on the stability of the ligand bonding to the surface and a further hydrolysis of the silica was investigated by subjecting the six modified phases to artificial ageing under simulated routine conditions.

\section{CHARACIERIZATION}

In order to describe the qualitative and quantitative changes in the RP-HPLC stationary phases, one should include both bulk and surface properties related to solid-liquid interactions determining chromatographic behaviour, as follows.

(a) Determination of bulk properties such as specific surface area, particle size,

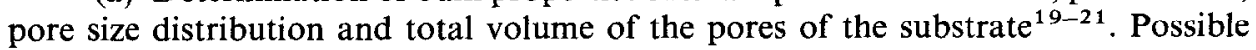
contamination with traces of metals should be regarded as important for the stability of the stationary phase. With the determination of the carbon content of the bulk phase and the specific surface area of the substrate, the average ligand surface density $\left(\alpha_{1}\right)$ can be calculated with an equation derived by Berendsen ${ }^{14}$ : 


$$
\alpha_{1}\left(\mathrm{~mol} \mathrm{~m}^{-2}\right)=\frac{P_{\mathrm{c}}}{S_{\mathrm{BET}}\left[M_{\mathrm{c}}-P_{\mathrm{c}}\left(M_{1}-1\right)\right]}
$$

where $P_{\mathrm{c}}=$ the amount of carbon $(\mathrm{g} / \mathrm{g}), S_{\mathrm{BET}}=$ specific BET surface area of the substrate $\left(\mathrm{m}^{2} \mathrm{~g}^{-1}\right), M_{\mathrm{c}}=$ the amount of carbon per mole of bonded silane $\left(\mathrm{g} \mathrm{mol}^{-1}\right)$ and $M_{1}=$ molecular weight of the silane molecule $\left(\mathrm{g} \mathrm{mol}^{-1}\right)$.

(b) Characterization of surface structure elements should include the nature of various groups present on the modified surface. This surface contains a variety of siliceous groups, such as different types of silanol, siloxane bridges and octadecyl ligands. High-resolution solid-state ${ }^{29} \mathrm{Si}$ NMR proved to be a suitable technique for determining changes in the ratios of these siliceous groups ${ }^{1,3,7,10,18}$. Solid-state ${ }^{29} \mathrm{Si}$ NMR not only distinguishes the different types of surface modifications (mono-, diand trifunctional) under study, but also provides details concerning surface and neighbour attachments ${ }^{22,23}$, via siloxane bonds, of the octadecylsilanes. This provides the possibility of studying the chemical reactions underlying the changes at different eluent compositions.

Until recently, only chromatographic experiments provided overall information on the changes in solid-liquid interactions between the stationary and the mobile phase after intensive use in laboratory practice. A more detailed chromatographic characterization of the stationary phases should be aimed at in order to relate the results of other stationary phase characterization methods. In this study, the chromatographic experiments were focused on changes in the amount of bonded ligands and selectivity. Alternatively, attention can be focused on the determination of the influence of the silica substrate by applying polar test solutes such as phenols, anilines or nitrobenzene, which are indicators of substrate interaction ${ }^{1,15,23}$. However, a reliable determination of substrate interactions with polar components will be hindered by both a varying silanol activity and the "memory effect" of previous injections, showing irreversible adsorption of the polar components. More fundamental chromatographic characterizations of RP-HPLC stationary phases were proposed by Smith ${ }^{24}$ and Jandera ${ }^{25-27}$ based on mainly solvophobic interactions of the eluting compounds with organic solvent-rich mobile phases.

The retention model proposed shows a linear relationship between the logarithm of the capacity factors, $k^{\prime}$, of a homologous series and the eluent composition:

$$
\log k^{\prime}=a-m x
$$

and

$$
\begin{aligned}
& a=a_{\mathrm{o}}+a_{1} n_{\mathrm{c}} \\
& m=m_{\mathrm{o}}+m_{1} n_{\mathrm{c}}
\end{aligned}
$$

where $x$ is the volume fraction of the organic part of the eluent (for binary eluents only), $n_{\mathrm{c}}$ is the incremental carbon number of a homologous series and $a_{0}, a_{1}, m_{\mathrm{o}}$ and $m_{1}$ are constants to be determined by regression. The validity of the regression has been extensively discussed ${ }^{1,26,27}$ and linearity with respect to eluent composition was shown at least in the range $60-90 \%(\mathrm{v} / \mathrm{v})$ of methanol for all octadecyl-modified 
stationary phases in this study. After elimination of the incremental carbon number of the eluting components from eqns. $3 a$ and $3 b$, Jandera ${ }^{25,26}$ derived

$$
m=q+p a
$$

where

$$
\begin{aligned}
& p=m_{1} / a_{1} \\
& q=m_{\mathrm{o}}-p a_{\mathrm{o}}
\end{aligned}
$$

As already shown by Jandera, the value of $p$ is independent of the stationary phase. An approximate theoretical calculation of the value of $p$ depends only on the type of eluent, especially the organic modifier ${ }^{26}$ :

$$
p \approx 2\left(1-\frac{I_{\text {org }}}{I_{\mathrm{H}_{2} \mathrm{O}}}\right)
$$

where $I_{\text {org }}=$ interaction index of the organic component of the mobile phase and $I_{\mathrm{H}_{2} \mathrm{O}}=$ interaction index of water. For binary methanol-water eluents, $I_{\mathrm{org}} / I_{\mathrm{H}_{2} \mathrm{O}}=$ 0.57 . With eqn. 6 , the theoretical value of $p$ is 0.86 and should be independent of the fraction of organic modifier used.

The constants $m_{\mathrm{o}}$ and $q$ in eqn. $5 \mathrm{~b}$ describe the selectivity ${ }^{26}: m_{\mathrm{o}}$ mainly non-specific, lipophilic selectivity and $q$ specific, polar selectivity. The value of $m_{\mathrm{o}}$ depends in practice on the character of the organic solvent in the mobile phase and the amount of bonded ligands of the stationary phase, whereas the value of $q$ should depend more on the nature of the homologous series residue or on the stationary phase involved for characterization. The $a_{0}$ value equals $\log k^{\prime}$ of the molecular residue (see eqns. 2 and $3 a$ ). The $a_{0}$ value of an essentially non-polar residue such as benzene should give a good indication of the phase ratio of the stationary phase used. A decrease in this $a_{\mathrm{o}}$ value expresses the loss of attached ligands. The $a_{\mathrm{o}}$ value of alkyl aryl ketones includes more specific intcractions between the alkyl aryl ketone residue and the stationary phase. The nature of these interactions is more complex and includes also polar interactions with the substrate.

\section{EXPERIMENTAL}

\section{Materials}

The test components used for chromatographic characterization were all of reference grade. Alkylbenzenes (test mixtue 1) used were benzene, methylbenzene, ethylbenzene, propylbenzene and butylbenzene. Alkyl aryl ketones (test mixture 2) used as test compounds were ethanophenone, propanophenone, butanophenone, pentanophenone, hexanophenone and octanophenone (Pierce, Rockford, IL, U.S.A.). All other solvents and chemicals used for simulating routine treatments and chromatographic characterization were of analytical-reagent grade (E. Merck, Darmstadt, F.R.G.) and demineralized, deionized water (Millipore Milli-Q system, Millipore, Bedford, MA, U.S.A.) was used. All eluents were freshly prepared and filtered over $0.22-\mu \mathrm{m}$ membrane filters (Millipore) prior to use. 


\section{Chromatography}

The six octadecylsilane-modified bonded phases were prepared at the Institut für Organische Chemie of the University of Tübingen, F.R.G. The modification with methylchlorooctadecylsilane, dimethylchlorooctadecylsilane and trichlorooctadecylsilane on two different silica substrates, Hypersil (batch 5-192, Shandon Southern Products, Runcorn, U.K.) and Nucleosil 100-7 (batch 5061, Macherey, Nagel \& Co., Düren, F.R.G.) was catalysed with 2,6-lutidine ${ }^{18}$. The bulk properties of the two silica substrates are listed in Table $\mathrm{I}$.

TABLE I

BULK PROPERTIES OF THE SILICA SUBSTRATES

\begin{tabular}{lcc}
\hline Property & Hypersil & Nucleosil 100-7 \\
\hline Batch No. & $5-192$ & 5061 \\
Mean particle size $(\mu \mathrm{m})$ & $5 \pm 1.5$ & $7 \pm 1.5$ \\
Mean pore size $(\mathrm{nm})$ & 12 & 10 \\
Specific surface $\mathrm{area}\left(\mathrm{m}^{2} / \mathrm{g}\right)$ & 170 & 350 \\
Pore volume $(\mathrm{ml} / \mathrm{g})$ & 0.7 & 1.0 \\
Iron content $(\mu \mathrm{g} / \mathrm{g})$ & $377 \pm 20$ & $76 \pm 10$ \\
Total silanol content ${ }^{a}(\mathrm{ratio} \times 100 \%)$ & 15.6 & 32.8 \\
Relative silanol ratios $(\times 100 \%)^{a}$ & 13.5 & 11.6 \\
$\quad$ Dihydroxysiloxane & 86.5 & 88.4 \\
$\quad$ Hydroxysiloxane & 0.092 & 0.093 \\
\hline Silanol density at the surface $\left(\text { contents } \times \mathrm{g} \mathrm{m}^{-2}\right)^{b}$ &
\end{tabular}

${ }^{a}$ Determined by deconvolution of the solid-state ${ }^{29}$ Si MAS NMR spectra of the substrates.

${ }^{b}$ Calibrated by dividing the total silanol content by the specific surface area.

A 25-g amount of silica substrate was activated at $160^{\circ} \mathrm{C}$ under reduced pressure for $24 \mathrm{~h}$. $\Lambda$ sample of $0.120 \mathrm{~mol}$ of dimethylchloro-, methyldichloro- or trichlorooctadecyl silane was melted and dissolved in $100 \mathrm{ml}$ of dry methylene chloride together with $0.15 \mathrm{~mol}$ of 2,6 -lutidine. The mixture was added to the activated silica still under vacuum and with vigorous stirring to avoid clotting. The reaction mixture was refluxed for $5 \mathrm{~h}$. The silica was then filtered and thoroughly washed with dry methylene chloride, ethanol, ethanol-water (50:50) and finally diethyl ether. The modified silicas were then dried at $50^{\circ} \mathrm{C}$ for $72 \mathrm{~h}$. Each stationary phase was packed in columns $(100$ $\mathrm{mm} \times 4 \mathrm{~mm}$ I.D.) (Knauer, Bad Homburg, F.R.G.) according to a standard packing procedure. From each series of seven columns of a typical phase, six columns were placed in an apparatus for simulating routine use after a chromatographic test to ensure reproducibility of the packing procedure, and the remaining column was used as a reference column for initial chromatographic tests. The equipment for simulating intensive routine use was described previously ${ }^{1}$. The artificial, strictly controlled ageing experiments consisted of continuous, separate exposure of columns packed with the $C_{18}$ phases under well defined conditions to several eluent compositions for a period of $240 \mathrm{~h}$. Basic and acidic aqueous and methanol-aqueous buffers were used (see Table II). The buffer solutions were prepared with equal amounts of buffer salt (calibrated for a total volume of 11 of aqueous or methanol-aqueous solution), titrated in aqueous solution to the $\mathrm{pH}$ values 3.0 for acidic and 8.4 for basic solutions. Subsequently an equal volume of methanol was added for aqueous-methanol buffers. 


\section{TABLE II}

\section{TREATMENTS FOR SIMULATING ROUTINE-USE EXPERIMENTS}

Each column purged with 7000 column volumes of a typical purging eluent; flow-rate $0.5 \mathrm{ml} / \mathrm{min}$; time $240 \mathrm{~h}$; ambient temperature.

\begin{tabular}{lllll}
\hline $\begin{array}{l}\text { Treat- } \\
\text { ment } \\
\text { No. }\end{array}$ & Buffer & $p H$ & $\begin{array}{l}\text { Volume fraction } \\
\text { of methanol in } \\
\text { the eluent }\end{array}$ & $\begin{array}{l}\text { Ion pairing agent } \\
\text { and concentration } \\
(M)\end{array}$ \\
\hline I & $0.05 M$ phosphate & 3.0 & 0 & - \\
II & $0.05 M$ phosphate & 3.0 & 0.5 & - \\
III & $0.05 M$ phosphate & 3.0 & 0.5 & Hexylsulphonate $(0.005)$ \\
IV & $0.05 M$ hydrogencarbonate & 8.4 & 0 & - \\
V & $0.05 M$ hydrogencarbonate & 8.4 & 0.5 & - \\
VI & $0.05 M$ hydrogeancarbonate & 8.4 & 0.5 & Triethylamine $(0.005)$ \\
\hline
\end{tabular}

In order to include a study of the effect of additional ionic species on bonded phases, at high $\mathrm{pH}$ a basic and at low $\mathrm{pH}$ an acidic ion-pairing agent were added to the methanol--water buffers. For economic and also practical reasons, these eluents were recirculated continuously in a closed system at a flow-rate of $0.5 \mathrm{ml} / \mathrm{min}$. Hence during the purging process each column was purged with about 7000 column volumes of a specific eluent. As already discussed by Claessens et al. ${ }^{1}$, possible saturation of the eluent with dissolved silica and/or ligands could reduce the ageing effect of the treatment. The influence of multiple sample introduction on the column is also neglected. Therefore, it seems reasonable to consider the results of the present experiments as the minimum changes during normal laboratory use for the different combinations of reversed phase and eluents.

After finishing a typical series of purging experiments, the columns were carefully rinsed with water, aqueous-methanol mixtures and methanol to prevent deposition of the buffering salts. Subsequently, the columns were subjected to chromatographic characterization with the two series of homologues, alkylbenzenes and alkyl aryl ketones, at a suitable eluent composition. These chromatographic experiments were performed with a Model 100 A pump (Beckman, Berkely, CA, U.S.A.), a Model CV-6-VHPa-N60 injection valve equipped with a $20-\mu l$ loop (Valco, Houston, TX, U.S.A.) and a Model LC-3 variable-wavelength UV detector (Pye Unicam, Cambridge, U.K.) operated at $254 \mathrm{~nm}$. Injections of 5-10 $\mu \mathrm{l}$ of the test mixtures were performed. The detector signal was sampled at $10 \mathrm{~Hz}$ and integrated with a Nelson 3000 data system (Nelson Analytical, Cupertino, CA, U.S.A.).

\section{Elemental analysis}

The carbon content of the modified $\mathrm{C}_{18}$ stationary phases prior to and after simulating routine treatment was obtained with a Perkin-Elmer Model 240 Analyzer (Perkin Elmer, Norwalk, CT, U.S.A.). Tungsten oxide was added to the modified silica as a catalyst. The carbon content, $P_{\mathrm{c}}$, and the ligand surface density, $\alpha_{1}$, of the starting materials are given in Table III. 
TABLE III

OCTADECYLSILANE-MODIFIED RP-HPLC STATIONARY PHASES UNDER STUDY, NOTATION, CARBON CONTENTS AND LIGAND SURFACE DENSITIES

\begin{tabular}{lllll}
\hline Substrate & Modification & $\begin{array}{l}\text { Abbre- } \\
\text { viation }\end{array}$ & $\begin{array}{l}\text { Carbon } \\
\text { content, }, \\
P_{c} \\
(\%, w / w)\end{array}$ & $\begin{array}{l}\text { Ligand surface } \\
\text { density, } \alpha_{1} \\
(\text { eqn. } 1) \\
\left(\mu m o l m^{-2}\right)\end{array}$ \\
\hline Nucleosil 100-7, batch 5061 & Dimethylchlorooctadecylsilane & NMO & 15.9 & 2.38 \\
& $\begin{array}{l}\text { Methyldichlorooctadecylsilane } \\
\text { Trichlorooctadecylsilane }\end{array}$ & NDI & 15.6 & 2.52 \\
Hypersil, batch 5-192 & NTR & 15.6 & 2.62 \\
& Dimethylchlorooctadecylsilane & HMO & 8.5 & 2.34 \\
& Methyldichlorooctadecylsilane & HDI & 8.7 & 2.55 \\
& Trichlorooctadecylsilane & HTR & 8.6 & 2.63 \\
\hline
\end{tabular}

\section{Solid-state ${ }^{29}$ Si NMR measurements}

The solid-state ${ }^{29} \mathrm{Si}$ NMR spectra were obtained on a Bruker CXP 300 Fourier transform NMR spectrometer at $59.63 \mathrm{MHz}$. Representative samples of 150-200 mg were spun at $c a .3 .5 \mathrm{kHz}$ using aluminium oxide rotors of the standard Bruker double-bearing type. ${ }^{29} \mathrm{Si}$ Bloch decay magic angle spinning (MAS) NMR spectra of the original silica substrates were obtained with a pulse interval time of $90 \mathrm{~s} .{ }^{29} \mathrm{Si}$ Bloch pulse MAS NMR is a time consuming technique but, when the pulse interval times exceed the relaxation times by a factor of $c a .5$, the signal areas measured represent the absolute amounts of silicon atoms of different nature present in the sample. Typically 1000 FIDs (free induction decays) with an acquisition time of $10 \mathrm{~ms}$ were accumulated in $1 \mathrm{~K}$ data points, zero-filled to $8 \mathrm{~K}$ prior to Fourier transformation. A line broadening of $10 \mathrm{~Hz}$ prior to zero-filling was used. ${ }^{29} \mathrm{Si}$ cross-polarization magic angle spinning (CP-MAS) NMR spectra of all modified $\mathrm{C}_{18}$ stationary phases prior to and after simulated routine treatment were obtained with a cross-polarization contact time of $6 \mathrm{~ms}$ for the monofunctionally modified stationary phases and $2 \mathrm{~ms}$ for the other modified phases. These respective values werc the optimum contact times for monoand multidentate surface-linked groups. The pulse interval was $1 \mathrm{~s} .{ }^{29} \mathrm{Si} \mathrm{CP}-\mathrm{MAS}$ NMR is confined to those silicon atoms not too far from protons near the surface and facilitates fast acquisition. Typically 2000 FIDs with an acquisition time of 10 ms were accumulated in $1 \mathrm{~K}$ data points, zero-filled to $8 \mathrm{~K}$ prior to Fourier transformation. The line broadening used was $20 \mathrm{~Hz}$ prior to zero-filling and Fourier transformation. The spectral width for all spectra was $20 \mathrm{kHz}$.

\section{RESULTS AND DISCUSSION}

The influence of long-term exposure to some aggressive eluents used in modern HPLC practice on the performance of a separation is illustrated best by chromatography itself. Fig. 1 depicts the chromatograms of alkylbenzenes (test mixture 1) eluted on methyldichlorooctadecylsilane-modified Nucleosil phases (NDI), before and after treatment III and IV. The characterization of the changes at the surface of the modified substrates after intensive use, the chemistry of the ageing proces, the impact on chromatography and stationary phase modification are discussed below. 


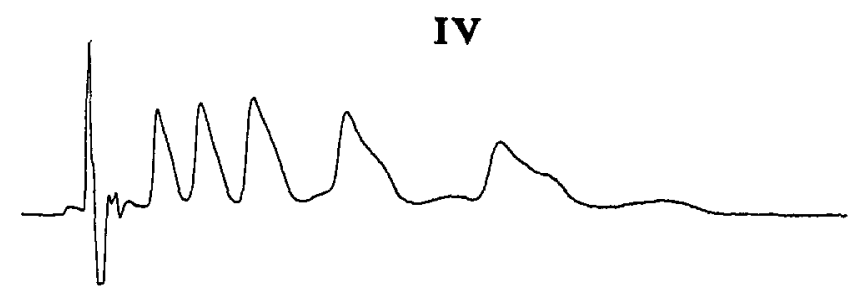

III
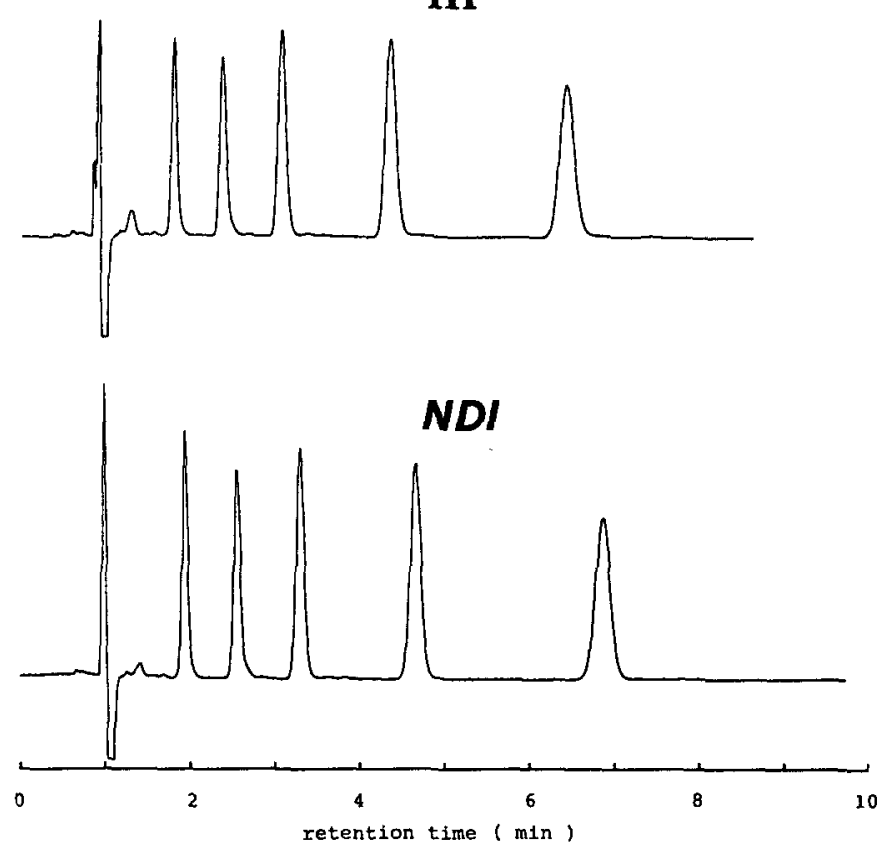

Fig. 1. Chromatograms of the untreated difunctional octadecylsilane-modified Nucleosil silica (NDI) and the identical stationary phase after treatments III and IV according to Table II. Chromatographic test conditions: test mixture 1, alkylbenzenes; water-methanol $(30: 70, \mathrm{v} / \mathrm{v})$; UV detection at $254 \mathrm{~nm}$.

\section{Condensation of multifunctional silanes}

The different types of surface silane modifications most relevant to this paper are collected in Table IV with their ${ }^{29} \mathrm{Si}$ NMR chemical shifts. The corresponding structural elements at the surface of the silica gel are depicted in Fig. 2.

The ${ }^{29} \mathrm{Si}$ MAS NMR spectra of both silica substrates are represented in Fig. 3. The relative amount of silanol groups, mainly hydroxysiloxane $\left(\mathrm{Q}_{3}\right)$ groups, determined from these spectra is given in Table I. Owing to the large surface area of the Nucleosil substrate and assuming that all silanol groups are located at the surface, an almost identical silanol density for both substrates was calibrated. In this study the total amount of geminal silanol, dihydroxysiloxane $\left(\mathrm{Q}_{2}\right)$ or silanediol groups of both substrates before modification did not exceed $15 \%$. Köhler et al.$^{3}$ reported a geminal silanol content of $32 \%$ relative to the total amount of silanol for various substrates, 
TABLE IV

MOST RELEVANT SURFACE SILANES/SILOXANES, THEIR FUNCTIONALITY, NOTATION AND TYPICAL ${ }^{29} \mathrm{Si}$ CHEMICAL SHIFTS

\begin{tabular}{lllll}
\hline Modification & $\begin{array}{l}\text { Chemical } \\
\text { (spectral) } \\
\text { function- } \\
\text { ality }\end{array}$ & $\begin{array}{l}\text { Topological } \\
\text { (network) } \\
\text { function- } \\
\text { ality }\end{array}$ & Code & $\begin{array}{l}\text { Typical chemical shift } \\
\text { (ppm downfield } \\
\text { from TMS) }\end{array}$ \\
\hline Dimethyloctadecylsiloxysilane & $\mathrm{M}$ & 1 & $\mathrm{M}_{1}$ & +12 \\
Methyloctadecylhydroxysiloxysilane & $\mathrm{D}$ & 1 & $\mathrm{D}_{1}$ & -3 \\
Methyloctadecyldisiloxysilane & $\mathrm{D}$ & 2 & $\mathrm{D}_{2}$ & -11 \\
Paired methyloctadecyldisiloxysilane & $\mathrm{D}$ & 2 & $\mathrm{D}_{2}^{\prime}$ & -16 \\
Octadecyldihydroxysiloxysilane $^{\prime}$ & $\mathrm{T}$ & 1 & $\mathrm{~T}_{1}$ & -48 \\
Octadecylhydroxydisiloxysilane $^{a}$ & $\mathrm{~T}$ & 2 & $\mathrm{~T}_{2}$ & -55 \\
Octadecyltrisiloxysilane $^{a}$ & $\mathrm{~T}$ & 3 & $\mathrm{~T}_{3}$ & -66 \\
Dihydroxysiloxane & $\mathrm{Q}$ & 2 & $\mathrm{Q}_{2}$ & -91 \\
Hydroxysiloxane & $\mathrm{Q}$ & 3 & $\mathrm{Q}_{3}$ & -101 \\
Tetrasiloxysiloxane & $\mathrm{Q}$ & 4 & $\mathrm{Q}_{4}$ & -110 \\
\hline
\end{tabular}

${ }^{a}$ Paired $T_{2}$ and $T_{3}$ groups and double-paired $T_{3}$ groups were not distinguishable.

determined by ${ }^{29}$ Si CP-MAS NMR. For untreated substrates we measured a lower content of geminal silanols relative to the total silanol content, about $12 \%$ for both silica substrates. For relative comparison, representative ${ }^{29} \mathrm{Si}$ CP-MAS NMR spectra of the monofunctional octadecylsilane-modified Nucleosil substrate, the difunctional

Monofunctional silanes Difunctional silanes Trifunctional silanes

Tetrafunctional siloxanes

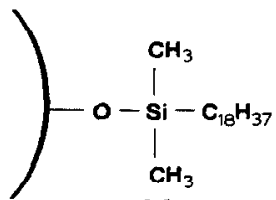

$M_{1}$<smiles>CCCCCC</smiles>

$D_{1}$<smiles>CCCCC[Si]1(C)OC(C)[C@H](C)O1</smiles><smiles>CCCCCCCC</smiles>

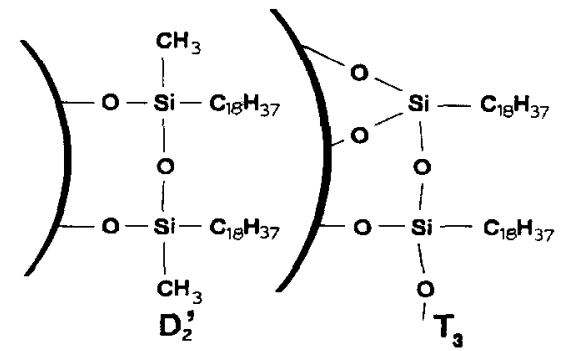<smiles>C[Si](C)(O)(O)(O)O</smiles><smiles>C[Si](C)(O)O[Si](C)(C)O</smiles><smiles>C[Si](C)O[Si](O[Si](C)(C)C)(O[Si](C)(C)C)O[Si](C)(C)C</smiles>

Fig. 2. Structure of the siliceous surface moieties most relevant to this paper with their notations. 

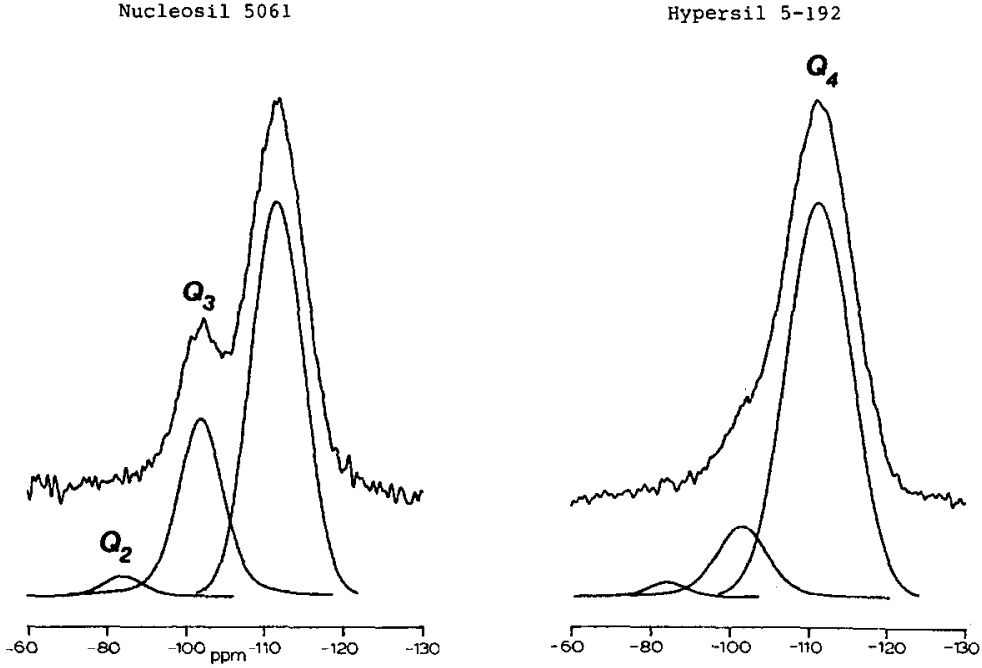

Fig. $3 .{ }^{29} \mathrm{Si}$ Bloch pulse MAS NMR spectra of the original Hypersil and Nucleosil silica substrates with the deconvoluted signals. $N_{\mathrm{s}}=1000$; pulse interval time, $90 \mathrm{~s}$; acquisition time, $10 \mathrm{~ms}$; line broadening, $10 \mathrm{~Hz}$.

octadecylsilane-modified Nucleosil substrate, the trifunctional octadecylsilane-modified Nucleosil and the trifunctional octadecylsilane-modified Hypersil substrate before and after treatments I, III and IV are shown in Figs. 4, 5, 6 and 7, respectively. The spectra of mono- and difunctional octadecylsilane-modified Hypersil were identical with those of the respective mono- and difunctional octadecylsilane-modified Nucleosil stationary phases. Only the spectra of the trifunctional modified Nucleosil and Hypersil stationary phases differed. For a direct comparison between the depicted spectra, one should consider the different contact times applied for mono- and multifunctionally modified phases, 6 and $2 \mathrm{~ms}$, respectively ${ }^{22}$. $\Lambda$ difference in contact time will alter the ratio between the $\mathrm{Q}_{3}$ and $\mathrm{Q}_{4}$ signals, which generally show different optimum contact times. To prevent the spectral difference, all untreated stationary phases were also measured with a $2 \mathrm{~ms}$ contact time. The $\mathrm{Q}_{3} / \mathrm{Q}_{4}$ ratio of all modified Nucleosil phases was found to be $1.22 \pm 0.02$ and for all modified Hypersil phases this value was $0.90 \pm 0.04$. The small spectral deviation indicated an equal residual silanol content after modification for all Nucleosil phases and also for all Hypersil phases.

The NMR spectra of the bonded phases indicate that the di- and trifunctional modified RP-HPLC phases under study tended to form more multidentate surface and neighbour linkages of the ocladecylsilane ligand, when used intensively with aqueous buffer solutions of high and low $\mathrm{pH}$ as eluents. Methyloctadecylhydroxysiloxysilane $\left(\mathrm{D}_{1}\right)$ and methyloctadecyldisiloxysilane $\left(\mathrm{D}_{2}\right)$ moieties reacted to form methyloctadecyldisiloxysilane, especially paired $\left(\mathrm{D}_{2}^{\prime}\right)$ moieties (see also Fig. 5). A similar condensation reaction occurred with the trifunctional octadecylsilane-modified stationary phases. Octadecyldihydroxysiloxysilane $\left(T_{1}\right)$ and octadecylhydroxydisiloxysilane $\left(T_{2}\right)$ moieties formed on modification were dehydrated to form octadecylhydroxydisiloxysilane $\left(T_{2}\right)$ and octadecyltrisiloxysilane $\left(T_{3}\right)$ moieties, respectively (see 


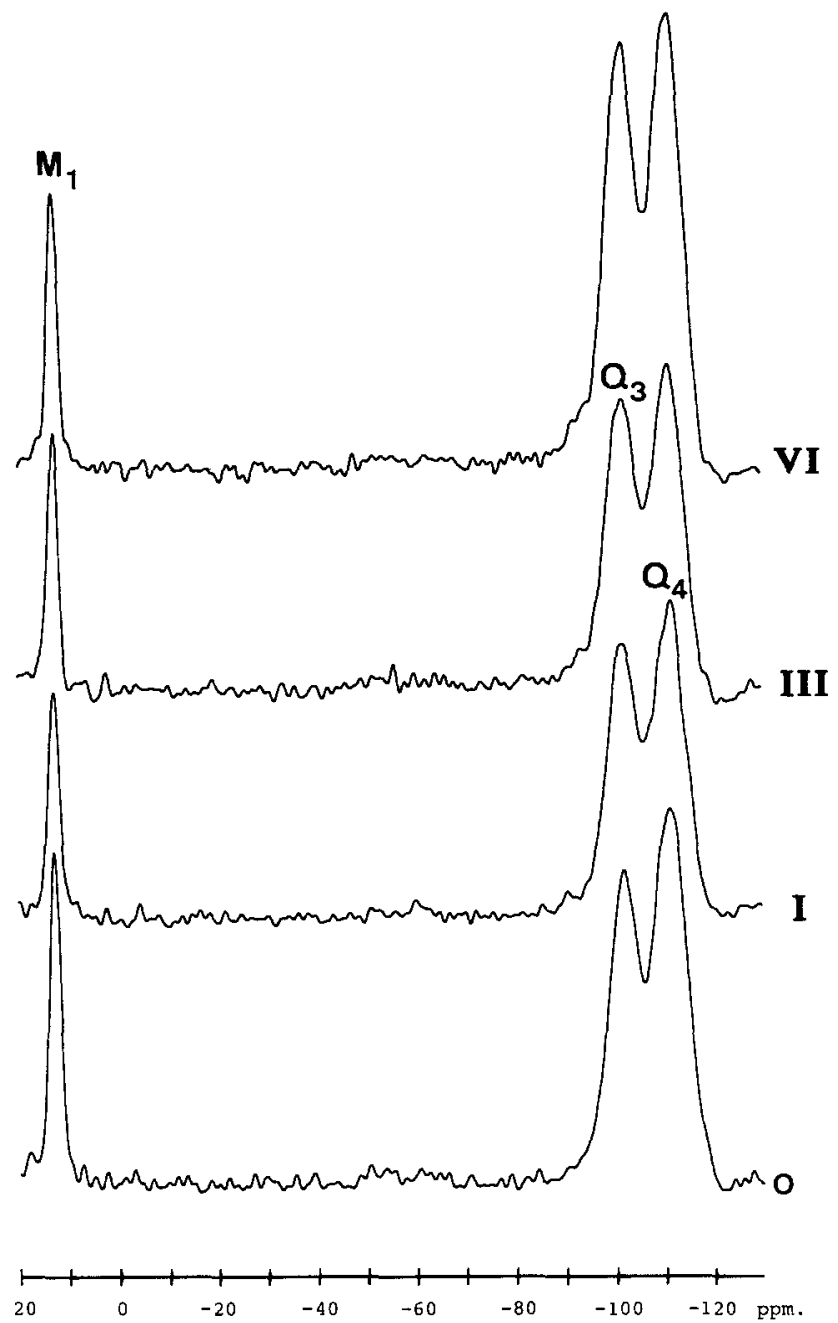

Fig. 4. ${ }^{29}$ Si CP-MAS NMR spectra of monofunctional octadecylsilane-modified Nucleosil silica, before (0) and after treatments I, III and VI. $N_{\mathrm{s}}=2000$; contact time, $6 \mathrm{~ms}$; interval time, $1 \mathrm{~s}$; acquisition time, $10 \mathrm{~ms}$; line broadening, $20 \mathrm{~Hz}$.

Figs. 6 and 7). The amount of surface silanol groups did not alter accordingly. On the contrary, a slight increase in surface silanol groups was noticed. From this we can conclude that condensation of hydroxysilane moieties at the surface $\left(\mathrm{D}_{1}, \mathrm{~T}_{1}\right.$ and $\left.\mathrm{T}_{2}\right)$ mainly occurred between anchored neighbours showing preferential polymerization across the surface. This is in agreement with the results of methyltrichlorosilane modifications of silica gels with different water contents published by Sindorf and Maciel $^{7}$. Our results indicate that multidentate linkage with other silanes at the surface prevented hydrolysis of the anchored ligands, in contrast to the monofunctionally modified octadecyl phases. In the latter instance, a substantial increase in silanol content is found during ageing. Condensation of multifunctional silanes was more 


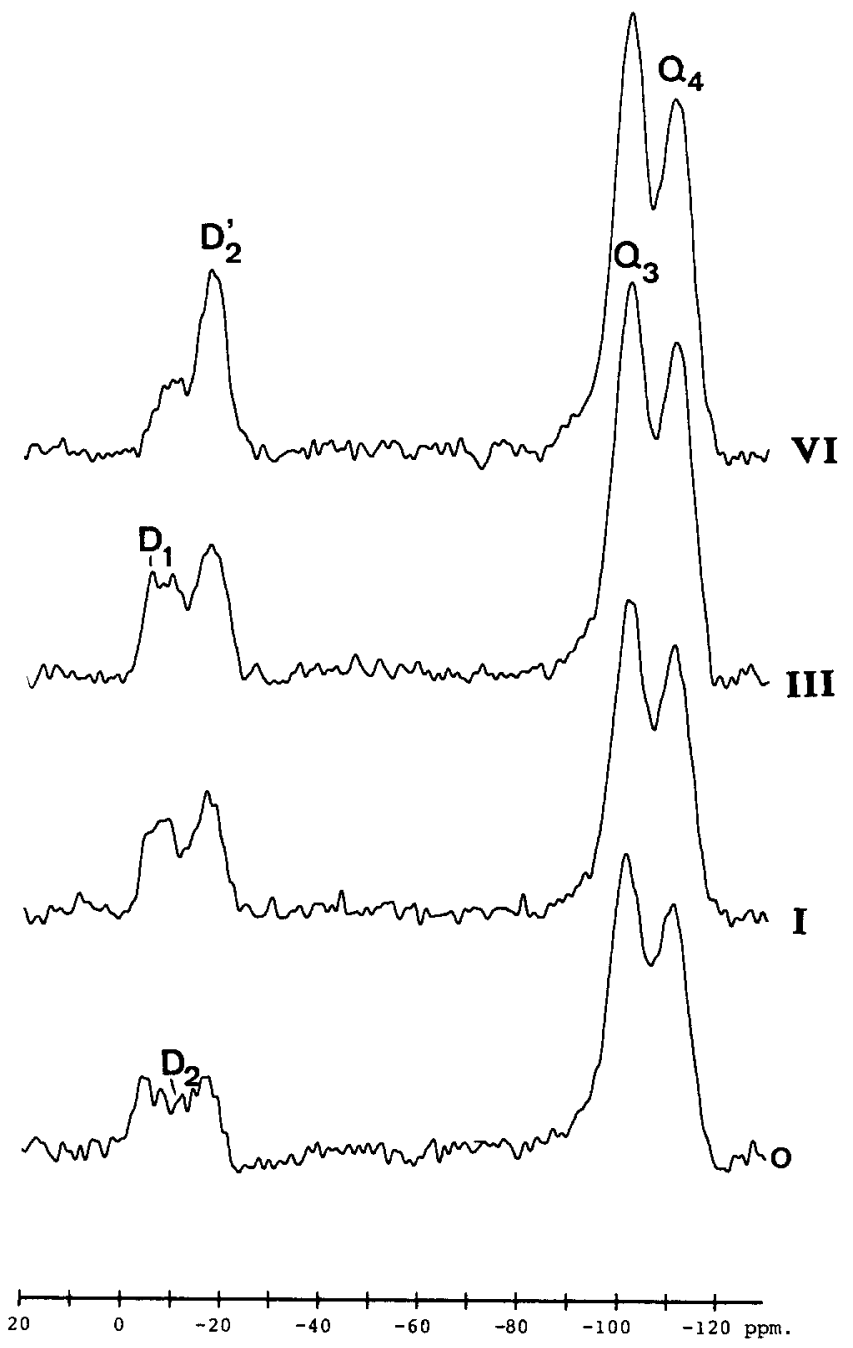

Fig. 5. ${ }^{29} \mathrm{Si} \mathrm{CP-MAS} \mathrm{NMR} \mathrm{spectra} \mathrm{of} \mathrm{difunctional} \mathrm{octadecylsilane-modified} \mathrm{Nucleosil} \mathrm{silica} \mathrm{before}(0)$ and after treatments I, III and VI. Conditions as in Fig. 4, except contact time, $2 \mathrm{~ms}$.

pronounced when buffers of high $\mathrm{pH}$ were used as eluents for simulation of intensive use.

The effect of ion pair agents added to aqueous-methanol buffers of low and high $\mathrm{pH}$ on the stationary phases studied here is not completely clear at this stage. All multifunctionally modified stationary phases except trifunctionally modified $\mathrm{Nu}$ cleosil showed an enhanced condensation of surface silanes on addition. For trifunctional octadecylsilane Nucleosil condensation was reduced by the methanol content of the aqueous-methanol buffer.

It should be noted that the trifunctionally modified Nucleosil used for the simulation experiments already showed progress of condensation of octadecyldi- 


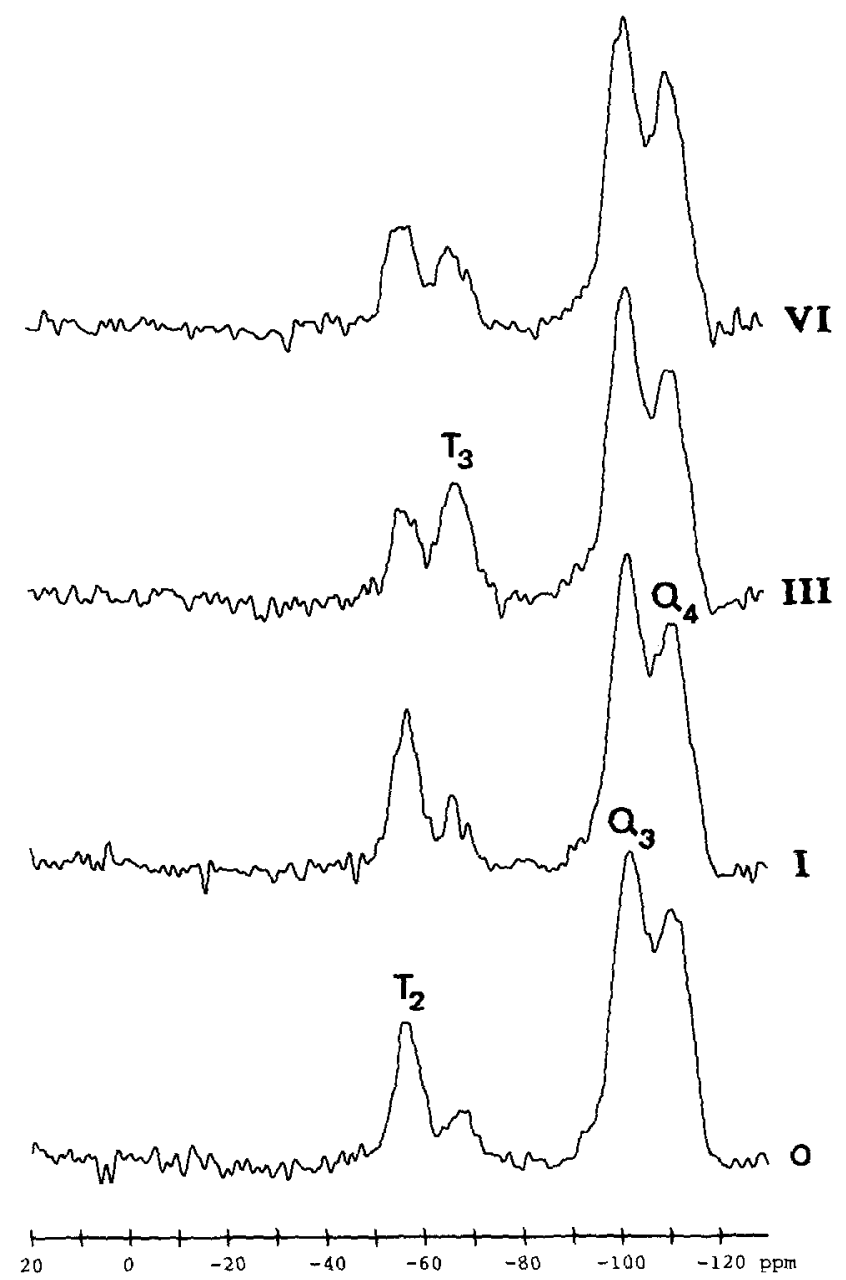

Fig. 6. ${ }^{29} \mathrm{Si} \mathrm{CP}$-MAS NMR spectra of trifunctional octadecylsilane-modified Nucleosil silica before (0) and after treatments I, III and VI. Conditions as in Fig. 5.

hydroxysiloxysilane $\left(\mathrm{T}_{1}\right)$ and octadecylhydroxydisiloxysilane ( $\left.\mathrm{T}_{2}\right)$ groups in the time elapsed between synthesis and the start of the chromatographic experiments. The concentration of $T_{1}$ groups was low and that of $T_{3}$ groups was much higher for the NTR phase than for the HTR phase used (see also Figs. 6 and 7). After a longer period no further changes at the surface of the trifunctionally modified Nucleosil were noticed.

The results of the spectroscopic and chromatographic measurements and the elemental analysis are summarized in Tables V-VII for modified Nucleosil silica and in Tables VIII-X for the modified Hypersil silica. 


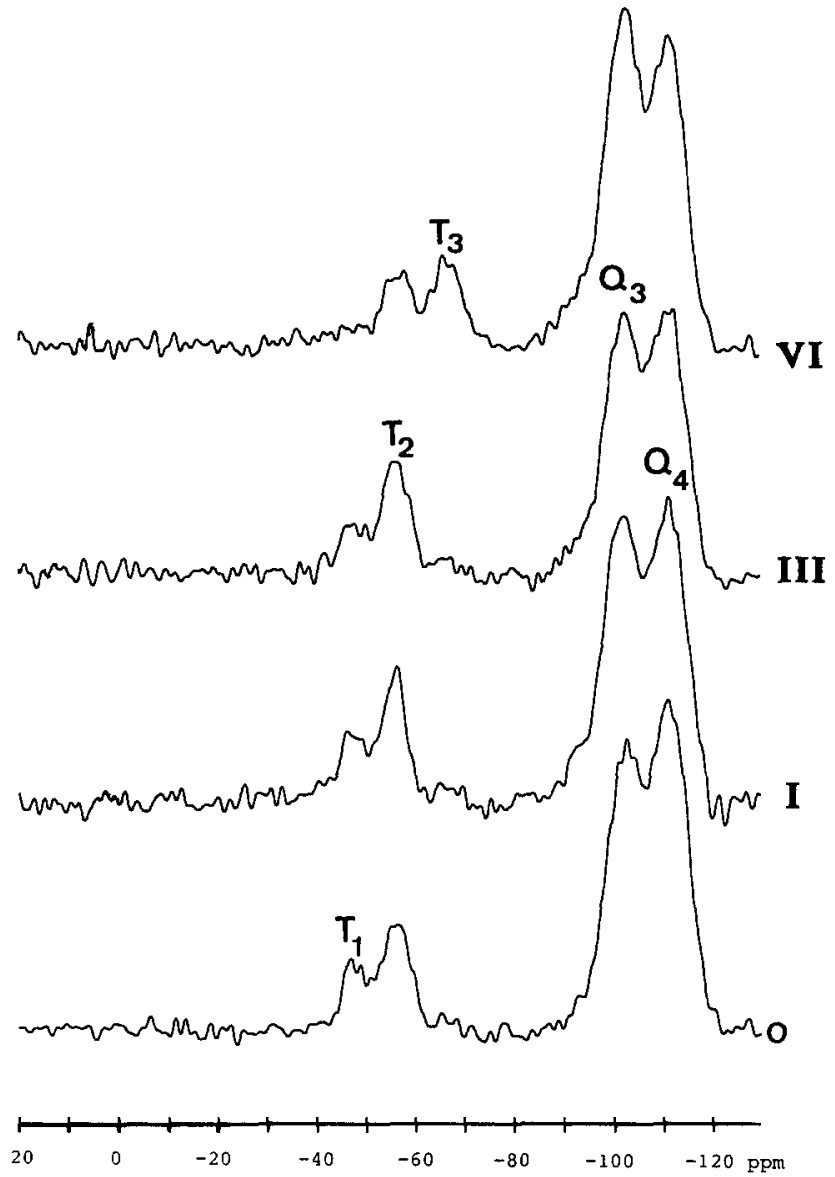

Fig. 7. ${ }^{29} \mathrm{Si} \mathrm{CP-MAS} \mathrm{NMR} \mathrm{spectra} \mathrm{of} \mathrm{trifunctional} \mathrm{octadecylsilane-modified} \mathrm{Hypersil} \mathrm{silica} \mathrm{before} \mathrm{(0)} \mathrm{and}$ after treatments I, III and VI. Conditions as in Fig. 5.

TABLE $V$

RESULTS OF ELEMENTAL ANALYSIS, NMR EXPERIMENTS AND CHROMATOGRAPHIC MEASUREMENTS OF THE MONOFUNCTIONAL OCTADECYLSILANE-MODIFIED NUCLEOSIL SILICA BEFORE AND AFTER TREATMENTS I-VI

Mean value of $p$ (eqn. 5a) $=0.80$.

\begin{tabular}{|c|c|c|c|c|c|}
\hline \multirow{2}{*}{$\begin{array}{l}\text { Stationary } \\
\text { phase } \\
\text { NMO } \\
\text { treatment }\end{array}$} & \multirow{2}{*}{$\begin{array}{l}\text { Ligand } \\
\alpha_{1}(\text { eqn. I) } \\
\left(\mu \mathrm{mol} \mathrm{m} \mathrm{m}^{-2}\right)\end{array}$} & \multicolumn{2}{|l|}{$N M R$} & \multicolumn{2}{|c|}{ Chromatography: $a_{o}$} \\
\hline & & $\begin{array}{l}\text { Ligand } \\
M_{1}\end{array}$ & $\begin{array}{l}\text { Silanol } \\
Q_{3}\end{array}$ & $\begin{array}{l}\text { Alkyl- } \\
\text { benzenes }\end{array}$ & $\begin{array}{l}\text { Alkyl aryl } \\
\text { ketones }\end{array}$ \\
\hline- & 2.38 & 0.34 & 0.66 & 2.22 & 0.81 \\
\hline I & 2.32 & 0.24 & 0.76 & 2.31 & 1.01 \\
\hline II & 2.31 & 0.32 & 0.68 & 2.34 & 0.41 \\
\hline III & 2.26 & 0.23 & 0.77 & 1.80 & 0.32 \\
\hline IV & 2.06 & 0.23 & 0.77 & 1.73 & 0.25 \\
\hline V & 2.13 & 0.32 & 0.68 & 1.76 & 0.32 \\
\hline VI & 2.11 & 0.28 & 0.72 & 1.91 & 0.21 \\
\hline
\end{tabular}


TABLE VI

RESULTS OF ELEMENTAL ANALYSIS, NMR EXPERIMENTS AND CHROMATOGRAPHIC MEASUREMENTS OF THE DIFUNCTIONAL OCTADECYLSILANE-MODIFIED NUCLEOSIL SILICA BEFORE AND AFTER TREATMENTS I-VI

Mean value of $p$ (eqn. 5a) $=0.65$.

\begin{tabular}{|c|c|c|c|c|c|c|c|}
\hline \multirow{3}{*}{$\begin{array}{l}\text { Stationary } \\
\text { phase } \\
\text { NDI } \\
\text { treatment }\end{array}$} & \multirow{3}{*}{$\begin{array}{l}\text { Ligand } \\
\alpha_{1}(\text { eqn. } 1) \\
\left(\mu \mathrm{mol} \mathrm{m} \mathrm{m}^{-2}\right)\end{array}$} & \multicolumn{4}{|c|}{$N M R$} & \multicolumn{2}{|c|}{ Chromatography: $a_{o}$} \\
\hline & & \multicolumn{3}{|c|}{ Ligand } & \multirow{2}{*}{$\begin{array}{l}\text { Silanol } \\
Q_{3}\end{array}$} & \multirow{2}{*}{$\begin{array}{l}\text { Alkyl- } \\
\text { benzenes }\end{array}$} & \multirow{2}{*}{$\begin{array}{l}\text { Alkyl aryl } \\
\text { ketones }\end{array}$} \\
\hline & & $D_{1}$ & $D_{2}$ & $D_{2}^{\prime}$ & & & \\
\hline- & 2.52 & 0.16 & 0.08 & 0.18 & 0.58 & 1.96 & 0.31 \\
\hline I & 2.45 & 0.19 & 0.03 & 0.16 & 0.62 & 1.76 & 0.15 \\
\hline II & 2.47 & 0.17 & 0.02 & 0.17 & 0.64 & 1.87 & 0.08 \\
\hline III & 2.50 & 0.15 & - & 0.21 & 0.64 & 1.45 & -0.05 \\
\hline IV & 2.32 & 0.12 & - & 0.22 & 0.66 & 1.36 & -0.07 \\
\hline V & 2.44 & 0.15 & - & 0.20 & 0.65 & 1.53 & -0.06 \\
\hline VI & 2.37 & 0.08 & - & 0.24 & 0.68 & 1.46 & -0.12 \\
\hline
\end{tabular}

Stationary phase hydrolysis

The influences of treatments I-VI on the capacity factors of the methyldichlorooctadecylsilane-modified Nucleosil (NDI) stationary phase for test mixture I are shown in Fig. 8 with the eluent methanol-water $(80: 20, \mathrm{v} / \mathrm{v})$. The decreased capacity factors after all treatments indicate a significant loss of ligands from the surface of the reversed phase. After extrapolation to $n_{\mathrm{c}}=0$ and $x=0$ (methanol fraction in the eluent used for characterization), the differences in capacity were expressed as the $a_{\mathrm{o}}$ values for the alkylbenzene test mixture (see below). A typical diagram of $\log k^{\prime}$, determined by regression analysis from chromatographic results, versus the volume

\section{TABLE VII}

RESULTS OF ELEMENTAL ANALYSIS, NMR EXPERIMENTS AND CHROMATOGRAPHIC MEASUREMENTS OF THE TRIFUNCTIONAL OCTADECYLSILANE-MODIFIED NUCLEOSIL SILICA BEFORE AND AFTER TREATMENTS I-VI

Mean value of $p$ (eqn. 5a) $=0.85$.

\begin{tabular}{|c|c|c|c|c|c|c|c|}
\hline \multirow{3}{*}{$\begin{array}{l}\text { Stationary } \\
\text { phase } \\
\text { NTR } \\
\text { treatment }\end{array}$} & \multirow{3}{*}{$\begin{array}{l}\text { Ligand } \\
\alpha_{1}(\text { eqn. } 1) \\
\left(\mu \mathrm{mol} \mathrm{m} \mathrm{m}^{-2}\right)\end{array}$} & \multicolumn{4}{|c|}{$N M R$} & \multicolumn{2}{|c|}{ Chromatography: $a_{o}$} \\
\hline & & \multicolumn{3}{|c|}{ Ligand } & \multirow{2}{*}{$\begin{array}{l}\text { Silanol } \\
Q_{3}\end{array}$} & \multirow{2}{*}{$\begin{array}{l}\text { Alkyl- } \\
\text { benzenes }\end{array}$} & \multirow{2}{*}{$\begin{array}{l}\text { Alkyl aryl } \\
\text { ketones }\end{array}$} \\
\hline & & $T_{1}$ & $T_{2}$ & $T_{3}$ & & & \\
\hline- & 2.62 & 0.02 & 0.24 & 0.10 & 0.64 & 2.06 & 2.44 \\
\hline I & 2.57 & - & 0.22 & 0.11 & 0.67 & 2.38 & -0.06 \\
\hline II & 2.56 & 0.03 & 0.21 & 0.05 & 0.71 & 2.11 & 1.34 \\
\hline III & 2.57 & - & 0.25 & 0.09 & 0.66 & 1.95 & 0.86 \\
\hline IV & 2.95 & - & 0.09 & 0.20 & 0.71 & 1.35 & -1.25 \\
\hline V & 2.58 & - & 0.11 & 0.15 & 0.74 & 1.72 & -0.04 \\
\hline VI & 2.55 & - & 0.16 & 0.13 & 0.71 & 1.97 & -0.83 \\
\hline
\end{tabular}


TABLE VIII

RESULTS OF ELEMENTAL ANALYSIS, NMR EXPERIMENTS AND CHROMATOGRAPHIC MEASUREMENTS OF THE MONOFUNCTIONAL OCTADECYLSILANE-MODIFIED HYPERSIL SILICA BEFORE AND AFTER TREATMENTS I-VI

Mean value of $p$ (eqn. 5a) $=0.84$.

\begin{tabular}{|c|c|c|c|c|c|}
\hline \multirow{2}{*}{$\begin{array}{l}\text { Stationary } \\
\text { phase } \\
\text { HMO } \\
\text { treatment }\end{array}$} & \multirow{2}{*}{$\begin{array}{l}\text { Ligand } \\
\alpha_{1}(\text { eqn. I) } \\
\left(\mu \mathrm{mol} \mathrm{m} \mathrm{m}^{-2}\right)\end{array}$} & \multicolumn{2}{|l|}{$N M R$} & \multicolumn{2}{|c|}{ Chromatography: $a_{o}$} \\
\hline & & $\begin{array}{l}\text { Ligand } \\
M_{1}\end{array}$ & $\begin{array}{l}\text { Silanol } \\
Q_{3}\end{array}$ & $\begin{array}{l}\text { Alkyl- } \\
\text { benzenes }\end{array}$ & $\begin{array}{l}\text { Alkyl aryl } \\
\text { ketones }\end{array}$ \\
\hline- & 2.34 & 0.29 & 0.71 & 2.37 & 0.99 \\
\hline I & 1.45 & 0.11 & 0.89 & 1.89 & 0.71 \\
\hline II & 1.81 & 0.22 & 0.78 & 2.28 & 0.34 \\
\hline III & 1.82 & 0.18 & 0.82 & 1.97 & 0.47 \\
\hline IV & 1.55 & 0.16 & 0.84 & 2.01 & -0.19 \\
\hline V & 1.79 & 0.18 & 0.82 & 1.73 & 0.86 \\
\hline VI & 1.63 & 0.17 & 0.83 & 1.98 & 0.06 \\
\hline
\end{tabular}

fraction methanol $(x)$ and the incremental carbon number of the alkylbenzene $\left(n_{\mathrm{c}}\right)$ for the methyldichlorooctadecylsilane-modified Hypersil (HDI) stationary phase after treatment $\mathrm{V}$ is shown in Fig. 9, where the linear dependence of the $\log k^{\prime}$ values on both the eluent composition and the incremental carbon number is shown. According to eqns. 2 and 3 , the $a_{0}, m_{0}, a_{1}$ and $m_{1}$ values were calculated by multiple linear regression. The validity of the regression was expressed by the correlation coefficient $(r)$. All correlation coefficients had values between 0.995 and 0.999 , indicating reliable values for all constants estimated by the regression model proposed by Jandera ${ }^{25}$. With eqn. $5 \mathrm{a}$ the matching values for $p$ were calculated.

\section{TABLE IX}

RESULTS OF ELEMENTAL ANALYSIS, NMR EXPERIMENTS AND CHROMATOGRAPHIC MEASUREMENTS OF THE DIFUNCTIONAL OCTADECYLSILANE-MODIFIED HYPERSIL SILICA BEFORE AND AFTER TREATMENTS I-VI

Mean value of $p$ (eqn. 5a) $=0.88$.

\begin{tabular}{|c|c|c|c|c|c|c|c|}
\hline \multirow{3}{*}{$\begin{array}{l}\text { Stationary } \\
\text { phase } \\
\text { HDI } \\
\text { treatment }\end{array}$} & \multirow{3}{*}{$\begin{array}{l}\text { Ligand } \\
\alpha_{1}(\text { eqn. } 1) \\
\left(\mu \mathrm{mol} \mathrm{m} \mathrm{m}^{-2}\right)\end{array}$} & \multicolumn{4}{|c|}{$N M R$} & \multicolumn{2}{|c|}{ Chromatography: $a_{o}$} \\
\hline & & \multicolumn{3}{|c|}{ Ligand } & \multirow{2}{*}{$\begin{array}{l}\text { Silanol } \\
Q_{3}\end{array}$} & \multirow{2}{*}{$\begin{array}{l}\text { Alkyl } \\
\text { benzenes }\end{array}$} & \multirow{2}{*}{$\begin{array}{l}\text { Alkyl aryl } \\
\text { ketones }\end{array}$} \\
\hline & & $D_{1}$ & $D_{2}$ & $D_{2}^{\prime}$ & & & \\
\hline- & 2.55 & 0.07 & 0.20 & 0.05 & 0.68 & 2.09 & 0.49 \\
\hline I & 2.39 & 0.05 & 0.15 & 0.12 & 0.68 & 1.91 & -0.29 \\
\hline II & 2.44 & 0.05 & 0.18 & 0.17 & 0.62 & 1.91 & 0.57 \\
\hline III & 2.45 & - & 0.17 & 0.16 & 0.67 & 2.01 & 0.49 \\
\hline IV & 2.29 & 0.04 & 0.14 & 0.11 & 0.71 & 1.90 & -0.36 \\
\hline V & 2.36 & 0.04 & 0.12 & 0.14 & 0.70 & 2.01 & 0.14 \\
\hline VI & 2.21 & 0.04 & 0.10 & 0.17 & 0.69 & 1.60 & 0.32 \\
\hline
\end{tabular}


TABLE $\mathrm{X}$

RESULTS OF ELEMENTAL ANALYSIS, NMR EXPERIMENTS AND CHROMATOGRAPHIC MEASUREMENTS OF THE TRIFUNCTIONAL OCTADECYLSILANE-MODIFIED HYPERSIL SILICA BEFORE AND AFTER TREATMENTS I-VI

Mean value of $p$ (eqn. 5a) $=0.84$.

\begin{tabular}{|c|c|c|c|c|c|c|c|}
\hline \multirow{3}{*}{$\begin{array}{l}\text { Stationary } \\
\text { phase } \\
\text { HTR } \\
\text { treatment }\end{array}$} & \multirow{3}{*}{$\begin{array}{l}\text { Ligand } \\
\alpha_{1}(\text { eqn. I) } \\
\left(\mu \text { mol } m^{-2}\right)\end{array}$} & \multicolumn{4}{|c|}{$N M R$} & \multicolumn{2}{|c|}{ Chromatography: $a_{0}$} \\
\hline & & \multicolumn{3}{|c|}{ Ligand } & \multirow{2}{*}{$\begin{array}{l}\text { Silanol } \\
Q_{3}\end{array}$} & \multirow{2}{*}{$\begin{array}{l}\text { Alkyl- } \\
\text { benzenes }\end{array}$} & \multirow{2}{*}{$\begin{array}{l}\text { Alkyl aryl } \\
\text { ketones }\end{array}$} \\
\hline & & $T_{1}$ & $r_{2}$ & $T_{3}$ & & & \\
\hline- & 2.63 & 0.18 & 0.18 & - & 0.64 & 1.97 & 0.51 \\
\hline I & 2.51 & 0.07 & 0.22 & - & 0.71 & 1.76 & 0.31 \\
\hline II & 2.54 & 0.10 & 0.22 & - & 0.68 & 1.82 & 0.48 \\
\hline III & 2.57 & 0.10 & 0.23 & - & 0.67 & 1.80 & 0.41 \\
\hline IV & 2.69 & - & 0.12 & 0.15 & 0.73 & 1.23 & -0.86 \\
\hline V & 2.40 & 0.02 & 0.15 & 0.11 & 0.72 & 1.54 & -0.06 \\
\hline VI & 2.38 & - & 0.12 & 0.14 & 0.76 & 1.37 & -0.70 \\
\hline
\end{tabular}

Both elemental analysis and solid-state ${ }^{29} \mathrm{Si}$ NMR measurements showed a significantly larger loss of ligands for monofunctionally modified stationary phases, especially for the Hypersil substrate, after simulation of intensive use. The effect of ligand loss was also registered by the $a_{\mathrm{v}}$ values determined for the alkylbenzene and alkyl aryl ketone homologous series. From theory it should be concluded that there is

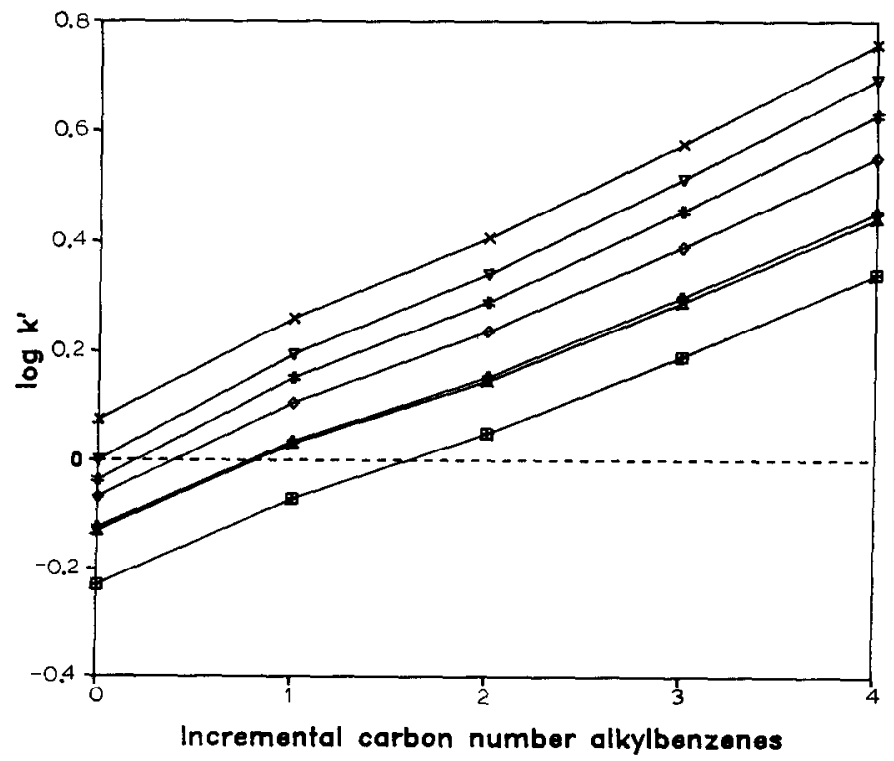

Fig. 8. Influence of treatments I-VI on the capacity factor $k^{\prime}$ determined by chromatography for alkylbenzenes (text mixture 1). Eluent: methanol-water $(80: 20, \mathrm{v} / \mathrm{v}) . \times, \mathrm{NDI}$, no treatment; $\nabla, \mathrm{NDI}, \mathrm{II} ; \neq$, NDI, I; $\diamond, N D I, ~ V ;+$, NDI, III; $\triangle$, NDI, VI; $\square$, NDI, IV. 


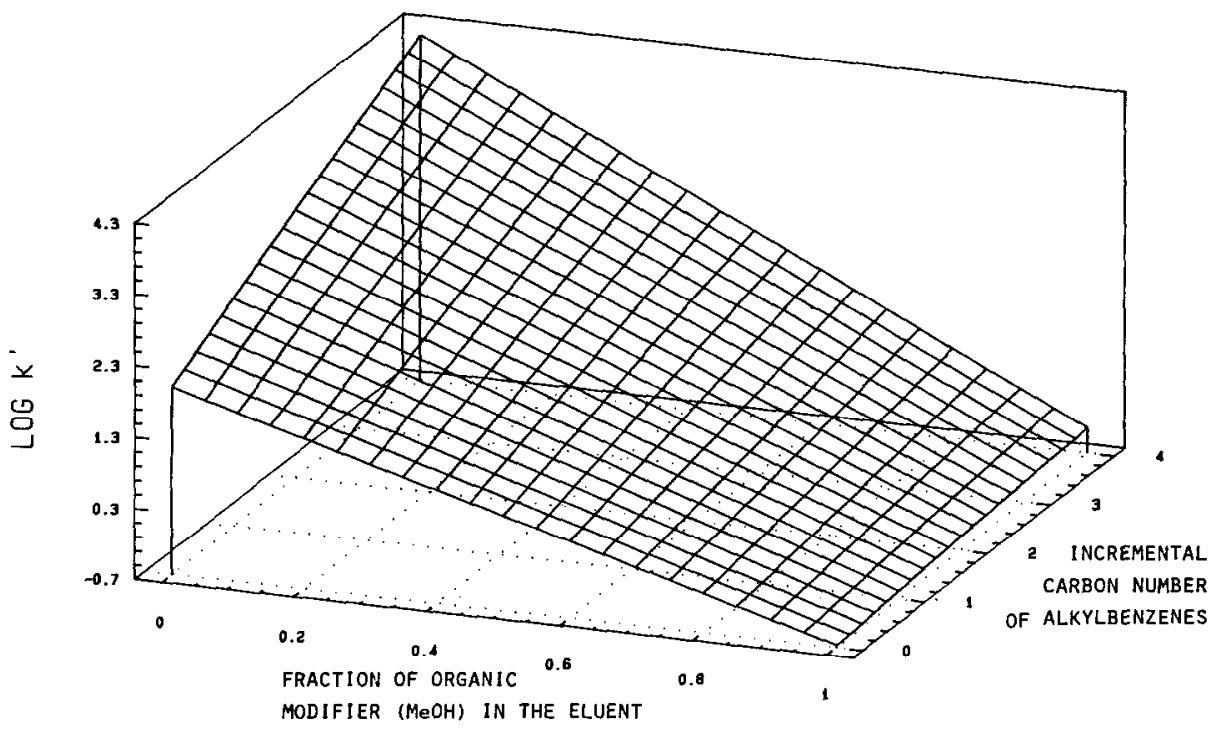

Fig. 9. Graphical representation of the regression function for $k^{\prime}$ with the volume fraction organic modifier (here methanol) in the eluent measured between $x=0.6$ and 0.9 and extrapolated for $x$ between 0 and 1 , and the incremental carbon number of the alkylbenzene homologous series for the difunctional octadecylsilanemodified Hypersil silica (HDI) after treatment V.

a correlation between especially the $a_{\mathrm{o}}$ values determined for alkylbenzenes and the ligand density $\alpha_{1}$ calculated with eqn. 1 after elemental analysis, both indicating eventual stripping of ligands from the surface of the silica. However, the observed correlation between $\alpha_{1}$ and $a_{\mathrm{o}}$ (alkylhenzene residue) for both stationary phases was poor, with correlation coefficients of $r$ (Nucleosil) $=0.70-0.86$ and $r$ (Hypersil) $=$ $0.56-0.85$. Plots of the $\alpha_{1}$ values as a function of the $a_{0}$ (alkylbenzene residue) values for both the Nucleosil and the Hypersil stationary phases are depicted in Figs. 10 and 11, respectively.

The $a_{\mathrm{o}}$ values fluctuated to a larger extent than the $\alpha_{1}$ values, especially for multifunctionally modified phases. The observed deviation between $\alpha_{1}$ and $a_{0}$ values is due to the fact that $\alpha_{1}$ is an averaged bulk value determined from the probably changed specific surface area and the relative carbon content, which is also influenced by hydrolysis of the substrate. On the other hand, the $a_{0}$ value seemed to be more sensitive to irregularities in the packing, such as local distortion of the ligand film and the packed bed, and chromatographic parameters.

New stationary phases with increasing ligand density showed a good correlation between the $a_{0}$ (alkylbenzene residue) and $\alpha_{1}$ values. The bonded phases modified with multifunctional silanes were more stable, in contradiction with results reported earlier ${ }^{1}$. This earlier study already contained a restrictive remark regarding the possible influence of a lower surface coverage of ligands for the trifunctional modified stationary phase studied. We can now conclude that the influence of different surface coverage is of major importance for the comparison of the stability of ligand anchoring on silica-based substrates, at least for multifunctionally derivatized materials. For 


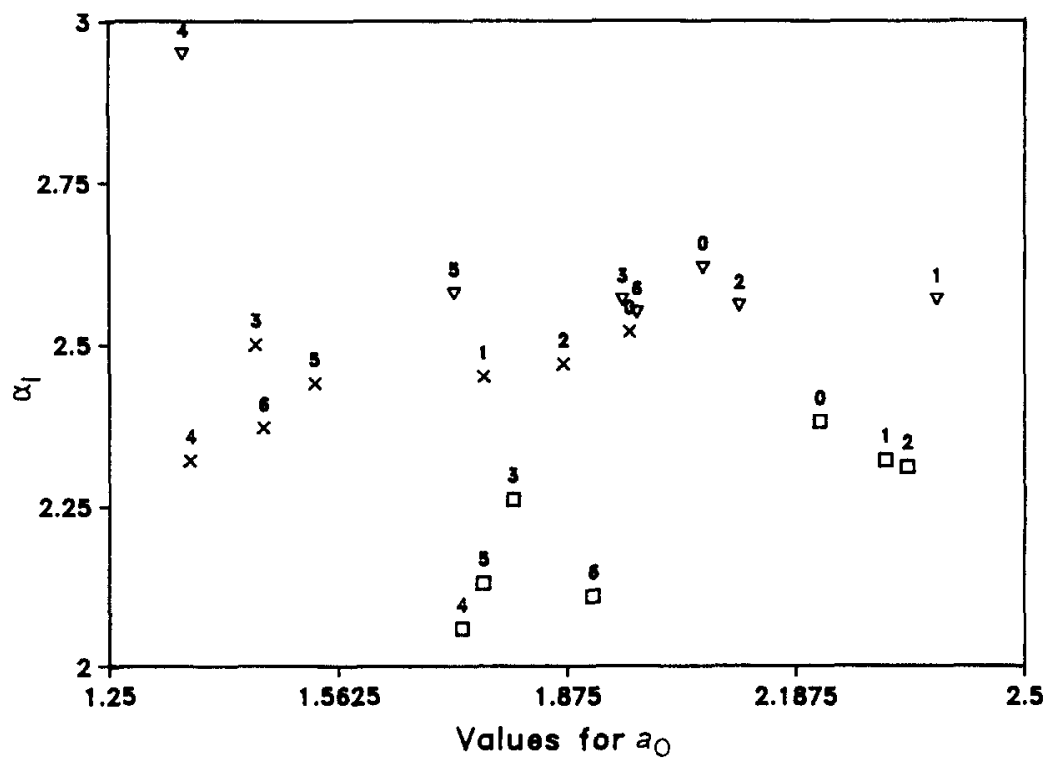

Fig. 10. Octadecyl ligand surface density $\alpha_{1}\left(\mu \mathrm{mol} \mathrm{m}^{-2}\right)$ versus $a_{\mathrm{o}}$ (alkylbenzenes) for modified Nucleosil stationary phases before $(0)$ and after each treatment (numbers $1-6$ represent treatments $I-V I) . \square$, NMO; $\times$, NDI; $\nabla$, NTR.

more stable stationary phases, full coverage of the surface with ligands is desirable. Hydrolysis of octadecyl ligands was reduced by eluents containing $50 \%(\mathrm{v} / \mathrm{v})$ methanol. Most severe hydrolyses of octadecylsilanes were determined after use of

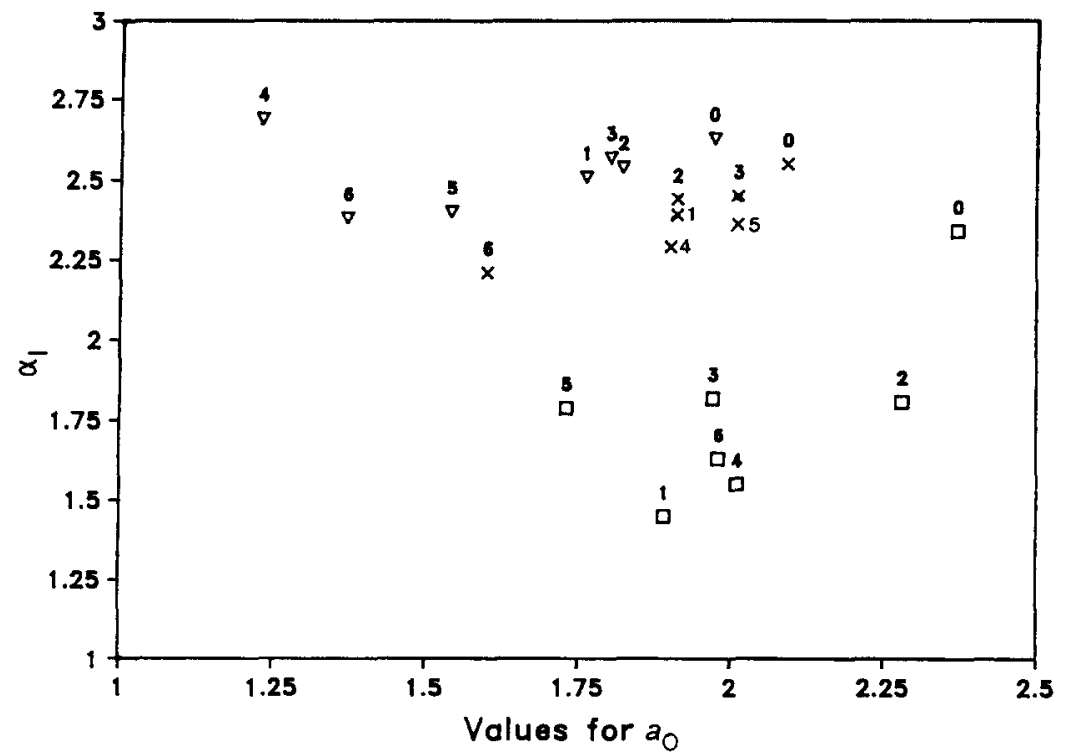

Fig. 11. Octadecyl ligand surface density $\alpha_{1}\left(\mu \mathrm{mol} \mathrm{m}^{-2}\right)$ versus $a_{\mathrm{o}}$ (alkylbenzenes) for modified Hypersil stationary phases before ( 0 ) and after each treatment (numbers $1-6$ represent treatments I-VI). $\square, \mathrm{HMO}$; $\times$, HDI; $\nabla$, HTR. 
high $\mathrm{pH}$ buffer eluents, especially with treatment IV. Elemental analysis sometimes showed an "increase" in the ligand density at the surface after treatment. This, however, is caused by rapid dissolution of the silica substrate rather than by extra hydrolysis of the silane ligands during ageing. The relatively higher hydrolysis of substrate material was only observed in this study for trifunctionally derivatized stationary phases. The same results, mainly for trifunctional modifications, were reported earlier ${ }^{1}$. Ligands attached to silica with trifunctional silanes were the most resistant towards hydrolysis when exposed to aggressive HPLC eluents compared with identically modified mono- and difunctional analogues. However, at high $\mathrm{pH}$ the shielding of the surface by polymerization did not prevent hydrolysis of the silica substrate, leading to a less preferable situation.

In a recent study, Kirkland et al. ${ }^{28}$ used bridged "bidentates", containing two monofunctional silicon atoms with short alkyl ligands $\left(\mathrm{C}_{1}-\mathrm{C}_{4}\right)$ instead of the difunctional alkylsilanes used for modification of the silica substrate in most other studies. They also noticed that these "bidentates" showed a higher resistance towards hydrolysis of the anchored silanes. We have noticed before that the anchoring of longer alkylsilane modifications was more stable owing to the shielding effect of these longer alkyl chains ${ }^{1}$. In this study, with difunctionally modified $\mathrm{C}_{18}$ phases the loss of ligands at the surface after the exposure treatments was limited to less than $10 \%$ relative to the initial carbon content, showing the highest stability towards hydrolysis by aggressive eluents. Compared with the short alkyl ligand modification described earlier ${ }^{1}$, the multifunctional octadecylsilane-modified stationary phases studied here show extremely high stabilities. Therefore, in order to improve the stability of alkyl-modified reversed phases with alkyl ligands longer than $\mathrm{C}_{4}$, the use of multifunctional alkylsilanes must be considered. This seems particularly true for bifunctional derivatized stationary phases.

Cracked particles and small channels formed through the packed column caused double and split peaks in chromatograms, as shown for the NDI phase after treatment IV in Fig. 1. These columns showed such a severe drop in column efficiency that any further use for chromatographic separations was inadvisable. For the trifunctionally modificd phases, more severe peak splitting occurred than for the difunctionally modified phases, indicating superior substrate shielding in the latter case.

The relative deviations of the results determined by the characterization methods used in this study are listed in Table XI. The relative deviations (RD) of the reported values were calibrated by comparing the determined values before and after treatment with the value before treatment (see eqn. 7):

$$
\mathrm{RD}=\frac{\sum_{i=1}^{n}\left|X_{\text {after }}-X_{\text {before }}\right|}{n} \cdot \frac{1}{X_{\text {before }}}
$$

where $X$ is the value determined by a specific characterization method and $n$ is the number of experiments or treatments performed.

These relative deviations give a summary of the results listed in Tables $\mathrm{V}-\mathrm{X}$ for comparison of the stabilities of the stationary phases examined. From the relative deviations for elemental analysis and solid-state ${ }^{29} \mathrm{Si}$ NMR experiments it can be 
TABLE XI

RELATIVE DEVIATION OF THE RESULTS DETERMINED BY ELEMENTAL ANALYSIS, NMR EXPERIMENTS AND CHROMATOGRAPHIC MEASUREMENTS FOR THE STATIONARY PHASES UNDER STUDY

\begin{tabular}{lllllll}
\hline $\begin{array}{l}\text { Stationary } \\
\text { phase }\end{array}$ & $\begin{array}{l}\text { Elemental } \\
\text { analysis: } \\
\alpha_{1}\end{array}$ & $\begin{array}{l}\text { NMR } \\
\end{array}$ & $\begin{array}{l}\text { Total } \\
\text { ligand }\end{array}$ & Silanol & & \multicolumn{2}{l}{$\begin{array}{l}\text { Chromatography: } a_{0} \\
\text { Alkyl- } \\
\text { benzenes }\end{array}$} & $\begin{array}{l}\text { Alkyl aryl } \\
\text { ketones }\end{array}$ \\
\hline NMO & 0.076 & 0.206 & 0.106 & 0.142 & 0.564 \\
NDI & 0.037 & 0.152 & 0.118 & 0.198 & 1.004 \\
NTR & 0.038 & 0.167 & 0.094 & 0.131 & 1.005 \\
HMO & 0.284 & 0.414 & 0.169 & 0.166 & 0.625 \\
HDI & 0.076 & 0.068 & 0.032 & 0.096 & 0.759 \\
HTR & 0.051 & 0.199 & 0.112 & 0.186 & 0.114 \\
\hline
\end{tabular}

concluded that on the Nucleosil substrate the di- and trifunctional octadecysilane stationary phases were more stable than the monofunctional octadecylsilane phase for the same surface coverage. The relative deviations of $a_{\mathrm{o}}$ (alkylbenzene) did not give a clear indication of the stability of the Nucleosil stationary phases. However, the trifunctional octadecyl phase was already altered by condensation before characterization and chromatographic treatments. This alteration could possibly have had a positive influence on the stability compared with the trifunctionally modified Hypersil stationary phase. On the Hypersil silica, however, the difunctional octadecylsilane modification manifested the highest stability after exposure to the HPLC eluents with the characterization methods used in this study. Compared with commercially available reversed-phase monofunctional octadecyl Hypersil phases, the ligand density in this study was relatively low $\left[\alpha_{1}=2.34\right.$ compared with $\alpha_{1}$ (commercial Hypersil $\left.\mathrm{C}_{18}\right)=3.41 \mathrm{~J}$. This probably explains the poor stability of the HMO stationary phase compared with a previous study ${ }^{1}$.

\section{Selectivity}

Selectivity in RP-HPLC depends on both the mobile and the stationary phase used. To judge the selectivity of the mobile phase, the mean values of $p$ are listed in Tables $\mathrm{V}-\mathrm{X}$. These $p$ values were in agreement with the theoretical value for methanol-water eluents $(p=0.86)$ calculated by Jandera ${ }^{26}$. The only exception was found for the NDI stationary phase with a mean value of $p=0.65$. This deviation was found after regression for both homologous test mixtures and was double checked. No reasonable explanation could be found for this deviation from the theoretical value.

More specific stationary phase-solute interactions were obtained from the values of $m_{\mathrm{o}}$ for lipophilic and $q$ for polar selectivity. The plots of $m_{\mathrm{o}}$ versus $a_{\mathrm{o}}$ for both homologue residues on the Nucleosil and Hypersil stationary phases are depicted in Figs. 12 and 13, respectively. As already pointed out by Jandera ${ }^{26,27}$, there is a good correlation between the non-polar contribution to the selectivity $m_{\mathrm{o}}$ and the capacity factor of the stationary phase represented by $a_{0}$ values. The correlation coefficients were $r$ (alkylbenzenes) $=0.92-0.98$ and $r$ (alkyl aryl ketones) $=0.97-0.996$. As 

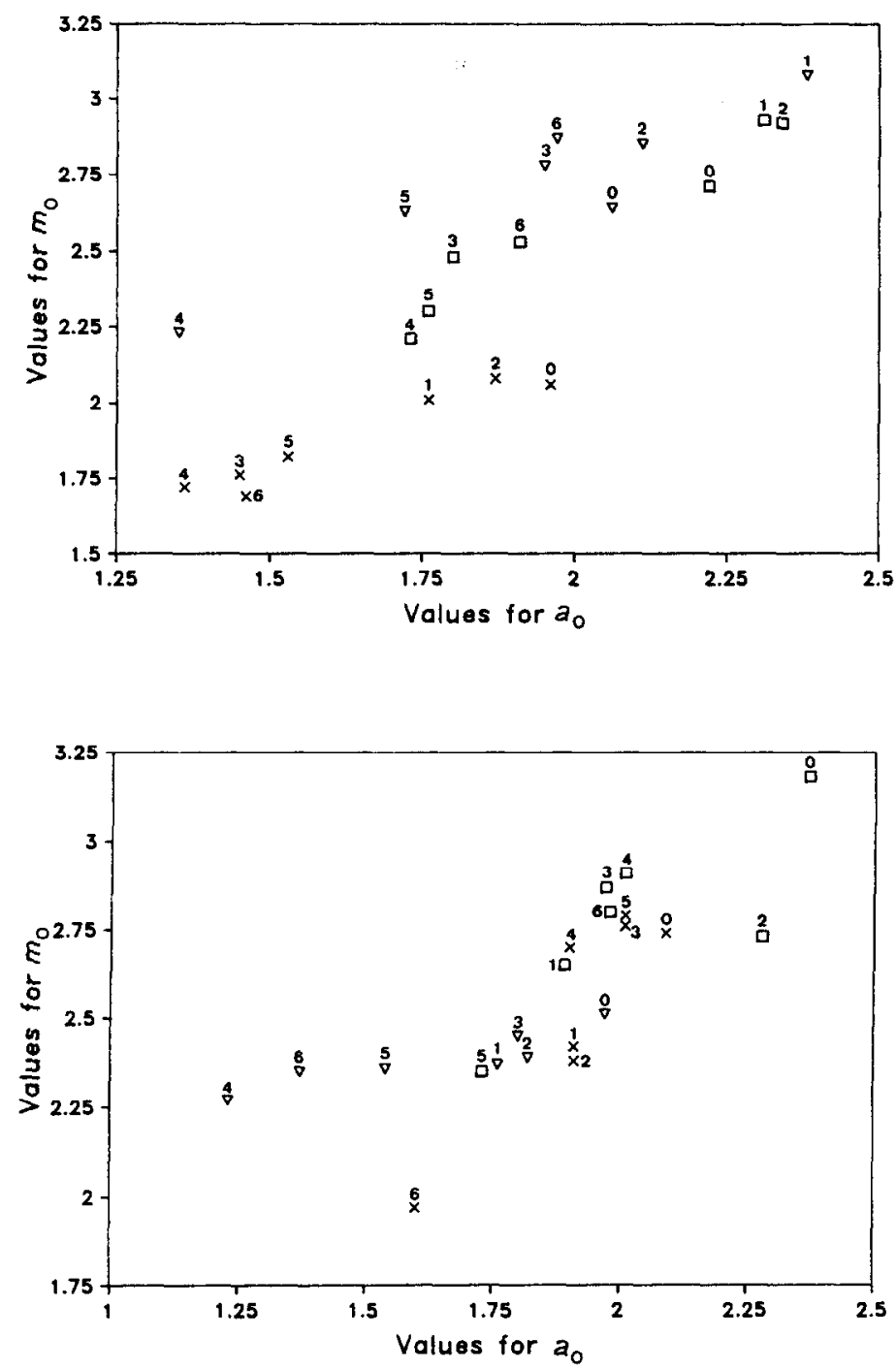

Fig. 12. Chromatographically determined $m_{\mathrm{o}}$ values (lipophilic selectivity) versus $a_{0}$ for the alkylbenzene homologous series on modified Nucleosil (top) and Hypersil (bottom) stationary phases before ( 0 ) and after each treatment (numbers $1-6$ represent treatments I-VI). Top: $\square$, NMO; $\times$, NDI; $\nabla$, NTR. Bottom: $\square$, HMO; $x$, HDI; $\nabla$, HTR.

expected, a decrease in the amount of bonded ligands caused by intensive use caused a decrease in non-specific lipophilic selectivity.

Plots of the polar selectivity $q$ versus $a_{\mathrm{o}}$ values for the alkyl aryl ketone residuc both on Nucleosil and Hypersil stationary phases are shown in Fig. 14. The influence of the exposure treatments on the polar selectivity varied depending on the type of modification and the silica substrate. For the monofunctionally modified phases a decrease in the capacity factor and lipophilic selectivity implies also a decrease in 

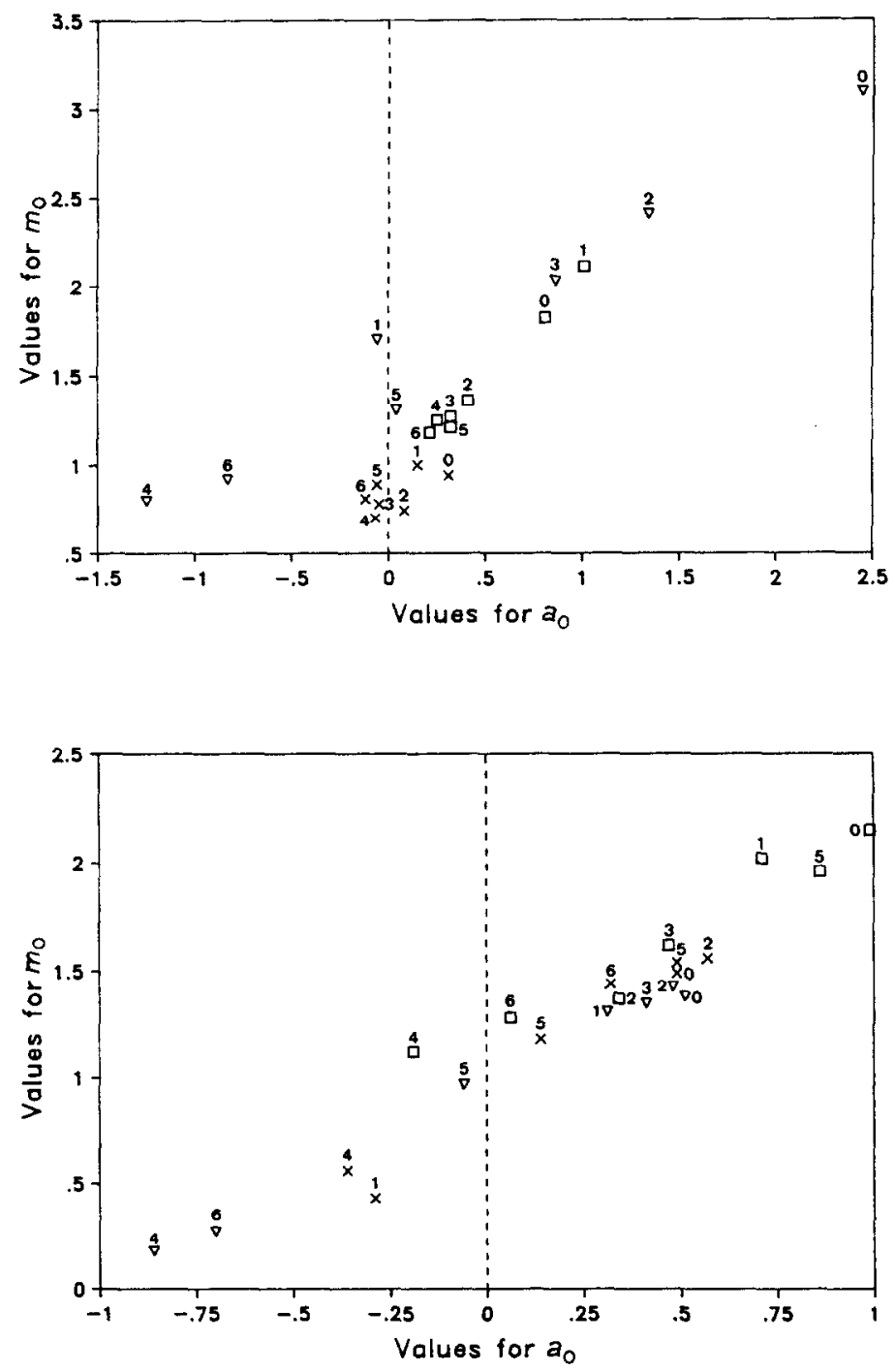

Fig. 13. Chromatographically determined $m_{\mathrm{o}}$ values (lipophilic selectivity) versus $a_{\mathrm{o}}$ for the alkyl aryl ketone homologous series on modified Nucleosil (top) and Hypersil (bottom) stationary phases before ( 0 ) and after each treatment (numbers $1-6$ represent treatments I-VI). Top: $\square$, NMO; $\times$, NDI; $\nabla$, NTR. Bottom: $\square$, HMO; $\times$, HDI; $\nabla$, HTR

polar selectivity for alkyl aryl ketones, and especially for the HMO stationary phase an extreme decrease in the $q$ value occurred. This polar selectivity seemed to decrease with the loss of ligands and the gain in silanol groups at the surface, against expectation.

Multifunctionally modified stationary phases, especially difunctionally modified phases, show an almost constant value of $q$ after hydrolysis and condensation of the remaining ligands at the surface. It seems that the residual silanols are better shielded by the surface cross-linked ligands, except for the trifunctional octadecyl- 

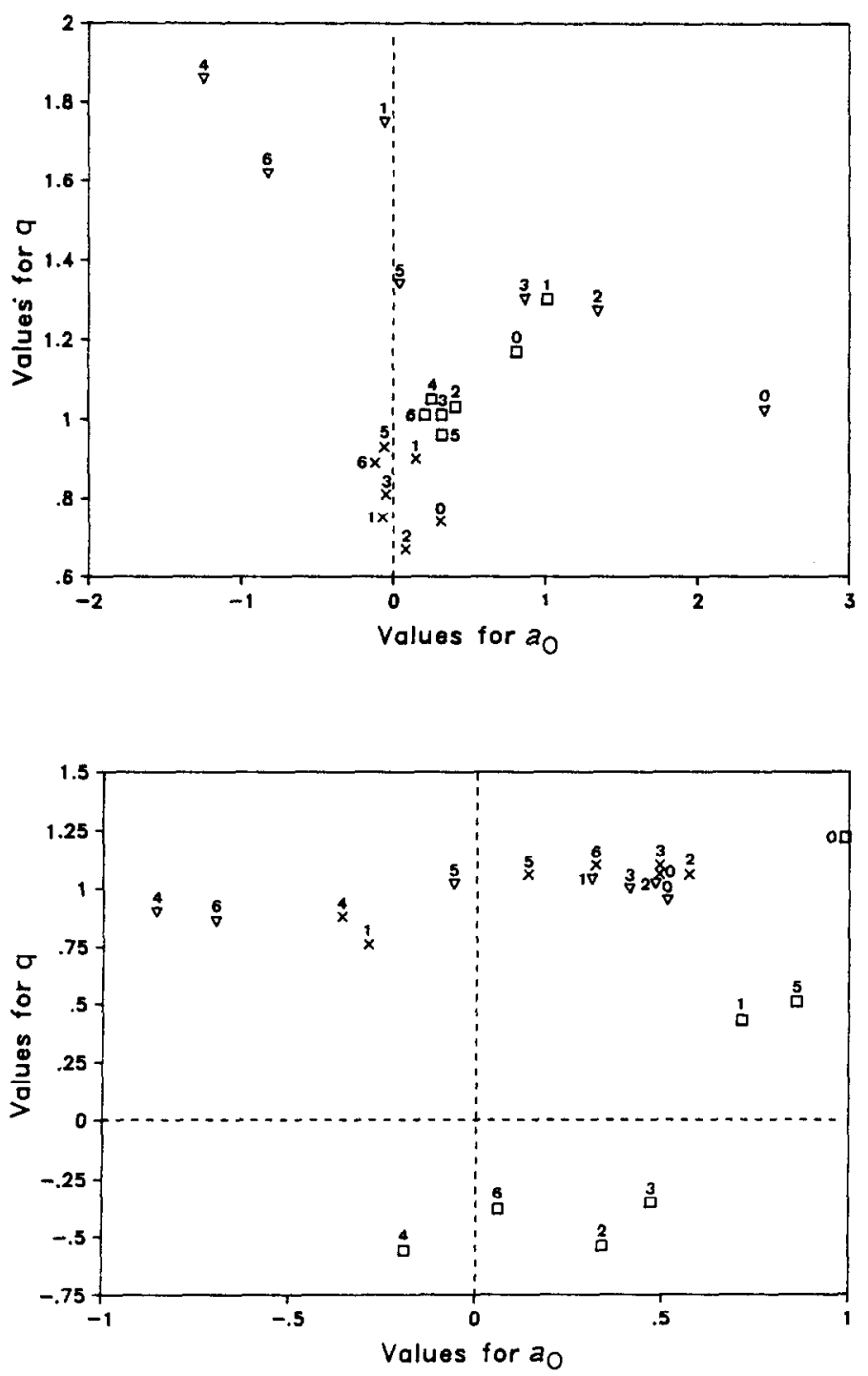

Fig. 14. Chromatographically determined $q$ values (polar selectivity) and $a_{\mathrm{o}}$ values for the alkyl aryl ketone homologous series on modified Nucleosil (top) and Hypersil (bottom) stationary phases before (0) and after each treatment (numbers $1-6$ repesent treatments I-VI). Top: $\square$, NMO; $\times$, NDI; $\nabla$, NTR. Bottom: $\square$, HMO; $\times$, HDI; $\nabla$, HTR.

modified Nucleosil phase. The substrate shielding of this stationary phase seems poor, indicated also by higher $q$ values after several treatments. Substrate shielding by siloxane bridges directly at the surface, which occurs especially with bidentate, difunctional octadecyl-modified phases, $\mathrm{D}_{2}$ and $\mathrm{D}_{2}^{\prime}$ groups, prevented ligand and substrate hydrolysis and showed a remaining selectivity after the exposure treatments. Difunctionally modified stationary phases with a bidentate linkage are to be preferred in RP-HPLC with aggressive eluents. 
In contrast with results published by Jandera ${ }^{27}$ on polar selectivity and the value of $q$ for solutes, we found that the value of $q$ (alkyl aryl ketones) did not indicate more specific polar interactions between the solute and the increasing amount of silanol groups measured by solid-state ${ }^{29} \mathrm{Si}$ NMR. Probably the "polarity" of the alkyl aryl ketone residue (steric hindrance of the benzene ring) and the shielding of the silanol groups formed, also due to a higher degree of mobility and irregularities in the octadecyl film ${ }^{29}$ after the exposure treatments, influenced these specific polar interactions negatively. More polar residues of homologous series are currently being investigated for future characterization of a more pronounced and discriminating value for the polar selectivity of different stationary phases before and after long-term exposure to aggressive eluents. As expected for the alkylbenzene residue, the value of $q$ did not change much. More or less equal $q$ values were determined even for the different silica substrates used for modification, owing to the rather apolar residue of the alkylbenzene homologous series.

\section{Exposure treatments, a practical guide}

A comparison between the effects of different exposure treatments can be used to evaluate the choice of the eluents listed in Table II. From the results of the different characterization techniques, it is obvious that eluents of both low and high $\mathrm{pH}$ should be included in the series of exposure treatments. For the aqueous buffer with $\mathrm{pH} 8.4$, used in treatment IV, severe degradation of the silica substrate was always observed. However, for more discriminating information about the stability of modified phases, the $\mathrm{pH}$ of the aqueous buffer should be selected at $c a$. 7.5, especially for less-stable RP-HPLC phases. Mixed eluents containing organic modifiers with aqueous buffers can be used with higher aqueous $\mathrm{pH}$ values, because the presence of the modifier decreases silica degradation. Although the effect of addition of ion pairing agents on the stability of the modified phases was moderate, the exclusion of these ionic species from the exposure treatments will deprive the experiments of additional, useful information. The present study involved a wide variety of eluents for exposure treatments.

For routine laboratory interest, a comparison of different stationary phases should be carried out with a more aggressive eluent than those used in practice to decrease the exposure time. Especially when aqueous eluents with abnormal $\mathrm{pH}$ values (below 4 and above 7) are to be used, one should consider "ageing" of the stationary phases. Information about the stability, selectivity, capacity and silica degradation can be obtainad by the chromatographic characterization method described above combined with information on the column efficiency.

\section{CONCLUSIONS}

Condensation of the multifunctional octadecylsilanes at the surface of the silica substrate prevented hydrolysis of the anchored ligands even after long-term exposure to aggressive eluents. For stationary phases synthesized in order to achieve identical degrees of silylation, we conclude that the bifunctional octadecylsilane stationary phases exhibited the best overall stability towards hydrolysis of the anchored ligands and hydrolysis of the silica substrate, especially when buffers of high $\mathrm{pH}$ were used as eluents. 
Difunctionally modified stationary phases with bidentate linkage are to be preferred in RP-HPLC with aggressive eluents. The decrease in capacity and lipophilic selectivity observed after long-term exposure was less pronounced for the multifunctionally derivatized stationary phases. Most multifunctionally modified octadecyl stationary phases showed an almost unchanged polar selectivity after intensive use. For the monofunctional phases a severe decrease in polar selectivity was determined.

For Nucleosil and Hypersil silica, differences in the type of silica substrate used appeared to have much less influence on hydrolysis for multifunctionally modified stationary phases than for monofunctionally modified phases. Of the two monofunctional octadecylsilane reversed phases, the Nucleosil-based phase seemed to be more resistant to aggressive eluents. The connection between the major substrate properties and stabilities of the stationary phases after modification will be the subject of further research in these laboratories.

\section{ACKNOWLEDGEMENTS}

We thank Mr. M. Kunst and Miss B. Pfleiderer for preparing the stationary phases, Mr. E. van Steen for assistance and Mr. H. Eding for the elemental analyses of the stationary phases. We thank Mr. H. Claessens for stimulating discussions and support. Further, the authors gratefully thank Mrs. Denise Tjallema for her expeditious handling of the manuscript. These investigations were supported by the Netherlands Foundation for Chemical Research (SON) with financial aid from the Netherlands Organization for Scientific Research (NWO).

\section{REFERENCES}

1 H. A. Claessens, J. W. de Haan, L. J. M. van de Ven, P. C. de Bruijn and C. A. Cramers, J. Chromatogr., 436 (1988) 345-365.

2 T. G. Waddell, D. E. Leyden and M. T. DeBello, J. Am. Chem. Soc., 103 (1981) 5303-5307.

3 J. Köhler, D. B. Chase, R. D. Farlee, A. J. Vega and J. J. Kirkland, J. Chromatogr., 352 (1986) 275-305.

4 J. Köhler and J. J. Kirkland, J. Chromatogr., 385 (1987) 125-150.

5 N. Sagliano, R. A. Hartwick, J. Bass, B. Woods and N. T. Miller, paper presented at the 12th International Symposium on Column Liquid Chromatography, Washington, DC, June 19-24, 1988.

6 Cs. Horvath (Editor), High Performance Liquid Chromatography, Vols. 1 and 2, Academic Press, New York, 1980.

7 D. W. Sindorf and G. E. Maciel, J. Am. Chem. Soc., 105 (1983) 3767-3776.

8 E. Bayer, K. Albert, J. Reiners, M. Nieder and D. Müller, J. Chromatogr., 264 (1983) 197-213.

9 H. Engelhardt and H. Müller, J. Chromatogr., 218 (1981) 395-407.

10 H. A. Claessens, C. A. Cramers, J. W. de Haan, F. A. H. den Otter, L. J. M. van de Ven, P. J. Andree, G. J. de Jong, N. Lammers, J. Wyma and J. Zeeman, Chromatographia, 20 (1985) 582-586.

11 A. M. Krstulovic, P. R. Brown, Reversed-Phase High Performance Liquid Chromatography, Wiley, New York. 1982.

12 J. L. Glajch, J. G. Gluckman, J. G. Charinkofsky, J. M. Minor and J. J. Kirkland, J. Chromatogr., 318 (1985) 23-29.

13 R. D. Golding, A. J. Barry and M. F. Barke, J. Chromatogr., 384 (1987) 105-116.

14 G. E. Berendsen, Ph.D. Thesis, Delft, 1980.

15 M. C. Hennion, C. Picard and M. Caude, J. Chromatogr., 166 (1978) 21-35.

16 C. Lüllmann, H. G. Genieser and B. Jastorff, J. Chromatogr., 323 (1985) 273-280.

17 J. N. Kinkel and K. K. Unger, J. Chromatogr., 316 (1984) 193-200.

18 E. Bayer, A. Paulus, B. Peters, G. Laup, J. Reiners and K. Albert, J. Chromatogr., 364 (1986) 25-37.

19 W. Noll, Chemie und Technologie der Siliconen, Verlag Chemie, Weinheim, 1968. 
20 R. K. Iler, The Chemistry of Silica, Wiley, New York, 1979.

21 K. K. Unger, Porous Silica, Elsevier, Amsterdam, 1979.

22 J. M. J. Vankan, J. J. Ponjeé, J. W. de Haan and L. J. M. van de Ven, J. Colloid Interface Sci., 126 (1988) 604-609.

23 H. Engelhardt, B. Dreyer and H. Schmidt, Chromatographia, 16 (1982) 242-246.

24 R. M. Smith, Anal. Chem., 56 (1984) 256-262.

25 P. Jandera, Chromatographia, 19 (1984) 101-112.

26 P. Jandera, J. Chromatogr., 314 (1984) 13-36.

27 P. Jandera, J. Chromatogr., 352 (1986) 91-110.

28 J. J. Kirkland, J. L. Glajch and R. D. Farlee, Anal. Chem., 61 (1989) 2-11.

29 K. Albert, B. Evers and E. Bayer, J. Magn. Reson., 62 (1985) 428-436. 